NBER WORKING PAPER SERIES

\title{
THE COSTS AND BENEFITS OF \\ GOING FROM LOW INFLATION \\ TO PRICE STABILITY
}

Martin Feldstein

Working Paper 5469

\author{
NATIONAL BUREAU OF ECONOMIC RESEARCH \\ 1050 Massachusetts Avenue \\ Cambridge, MA 02138 \\ February 1996
}

Professor of Economics, Harvard University, and president of the National Bureau of Economic Research. This paper is part of the NBER study of monetary policy in low inflation economies and was presented at the project conference on January 12-13, 1996. I am grateful to James Poterba and to the participants in the project and the conference for comments and suggestions and to Erzo Luttmer for research assistance and discussions. This paper is part of NBER's research program in Public Economics. Any opinions expressed are those of the author and not those of the National Bureau of Economic Research.

(C) 1996 by Martin Feldstein. All rights reserved. Short sections of text, not to exceed two paragraphs, may be quoted without explicit permission provided that full credit, including () notice, is given to the source. 


\title{
THE COSTS AND BENEFITS OF GOING FROM LOW INFLATION TO PRICE STABILITY
}

\begin{abstract}
This paper evaluates the welfare gain from achieving price stability and compares it to the cost of the transition. In calculating the gain from price stability, the paper emphasizes the distortions caused by the interaction of inflation and capital income taxes. Because inflation exacerbates the tax distortions that would exist even with price stability, the annual deadweight loss of a two percent inflation rate is a surprisingly large one percent of GDP. Since the real gain from shifting to price stability grows in perpetuity at the rate of growth of GDP, its present value is a substantial multiple of this annual gain. Discounting the annual gains at the rate that investors require for risky equity investments (i.e., at the 5.1 percent real net-of-tax rate of return on the Standard and Poors portfolio of equities from 1970 to 1994) implies a present value gain equal to more than 35 percent of the initial level of GDP. Since the estimated cost of shifting from two percent inflation to price stability is about five percent of GDP, the gain substantially outweighs the cost of transition.
\end{abstract}

Martin Feldstein

National Bureau of Economic Research 1050 Massachusetts Avenue

Cambridge, MA 02138 


\title{
The Costs and Benefits of Going from Low Inflation to Price Stability
}

\author{
Martin Feldstein*
}

There is now widespread agreement in the economics profession that "high" rates of inflation have significant adverse consequences and that these adverse effects justify the sacrifices in employment and output that are generally needed to reduce inflation. ${ }^{1}$ There is, however, much less professional support for the goal of "price stability" that central bankers advocate and that many governments and central banks are now seeking. The purpose of this paper is to examine the economic case for making the transition from low inflation to price stability.

Because measurement problems cause official inflation measures to overstate the rate of increase of buying a constant utility bundle of goods and services, price stability is generally taken to mean a measured inflation rate of about two percent. ${ }^{2}$ The analysis in this paper therefore addresses the following question: If the true and fully anticipated rate of inflation (i.e.,

${ }^{1}$ See, e.g., Fischer $(1981,1994)$. This has not always been so. Until the late 1970s, there were many economists in the United States who argued that the cost of reducing the existing rate of inflation was too high and that the economy should learn to live with moderate rates of inflation. The high rate of inflation in the late 1970s and early 1980 s together with the rapid disinflation during the early 1980 s appears to have virtually eliminated professional support for that view.

${ }^{2}$ This has been made explicit by the Federal Reserve and the Bundesbank among other central banks.

* Professor of Economics, Harvard University, and president of the National Bureau of Economic Research. This paper is part of the NBER study of monetary policy in low inflation economies and was presented at the project conference on January 12 - 13, 1996. I am grateful to James Poterba and to the participants in the project and the conference for comments and suggestions and to Erzo Luttmer for research assistance and discussions. 
the measured rate of inflation minus two percentage points) has stabilized at two percent, is the gain from reducing inflation to zero worth the sacrifice in output and employment that would be required to achieve it? $?^{3}$

To answer this question it is important to recognize that the cost of reducing inflation is a "one time" loss of output and employment while the benefit of a lower inflation rate is permanent. The appropriate "cost benefit analysis" of reducing inflation is therefore a comparison of the one-time cost of reducing inflation with the present value of the permanent benefits of price stability. ${ }^{4}$ The calculations presented in this paper show that the present value of the benefits of price stability exceed the costs of getting there. For the most plausible parameter values, the benefits of price stability exceed the costs of transition within six to nine years. For some parameter combinations, the relative gains are even larger. In every case, the present value of the benefits exceed the costs even when the benefits are discounted at the rate of return that individuals receive on a risky portfolio of common stocks.

This way of stating the problem makes it clear that it is not necessary to ask whether the benefit of price stability relative to a two percent inflation rate is "large" in some absolute sense (whatever that might mean) but only whether it is large enough to exceed the cost of transition.

${ }^{3}$ Since it is the "true" rate of inflation that matters, I will subtract two percentage points of inflation from the measured rate of inflation in all of the calculations presented in this paper.

${ }^{4}$ There may of course be shocks in the future that raise or lower the inflation rate. I will not deal with this explicitly, focusing on the comparison of stable inflation at two percent versus price stability. Because the net benefit (i.e., the present value of the benefits of lower inflation minus the net cost of the change in inflation) is essentially constant in the range that we are considering, the appropriate response to such future inflation shocks is just a repetition of the basic problem discussed in this paper. 
Similarly, the relevant policy decision does not depend on whether a higher rate of inflation reduces the rate of economic growth if it reduces the level of real income in each future year. ${ }^{5}$

Since the reduction in real income caused by inflation is proportional to national income, the annual benefit of having a lower rate of inflation grows over time (even though the rate of growth itself is unaffected.) To see the implications of this, note that discounting an annual benefit equal to $\mathrm{x}$ percent of GDP at a discount rate of $\mathrm{d}$ in an economy that grows at 2.5 percent a year (the rate of growth of U.S. real GDP from 1970 through 1994) yields a present value of $\mathrm{x} /(\mathrm{d}-0.025)$

Although a case could be made for discounting at a very low risk-free rate of return, to be more conservative I will use the return that individuals receive on a risky portfolio of corporate stocks. During the past quarter century, the real net-of-tax return that an individual investor received on an investment in the Standard and Poors composite was 5.1 percent. ${ }^{6}$ An annual benefit of $x$ percent of GDP therefore has a present value of $x /(.051-.025)=38.5 \mathrm{x}$. The evidence discussed in section 1 of this paper implies that the likely cost of reducing inflation from two percent to zero is equal to between four percent and six percent of the initial GDP. Even using the upper limit of six percent implies that the benefits of disinflation outweigh the costs if the annual benefit of lower inflation exceeds $x^{*}=6.0 / 38.5=0.16$ percent of GDP. The

${ }^{5}$ Barro (1995) presents evidence showing that there is no statistically significant relation between inflation and growth when the rate of inflation is under ten percent.

${ }^{6}$ Between 1970 and 1994, the Standard and Poors index rose at a nominal rate of 6.4 percent. The average dividend yield was 4.0 percent. The rate of increase of the consumer price index was 5.7 percent, implying a "true" inflation rate of 3.7 percent. Assuming a 25 percent marginal rate of tax on dividends and a 10 percent effective rate of tax on capital gains implies a real net return on the Standard and Poors portfolio of $0.75(4.0)+0.90(6.4)-3.7=5.1$ percent. 
analysis in sections 2 through 5 of this paper implies that the annual benefit substantially exceeds this critical value with the most plausible value of the annual gain being equal to about one percent of GDP, indicating that the gain from price stability would outweigh the costs of getting there from the current low level of inflation even if those gains were discounted at a very much higher rate.

The emphasis in my analysis is on the distortion in the process of household capital accumulation that occurs because of the interaction of inflation and tax rules' and on the consequence of that distortion for tax revenue. One important aspect of this is the negative effect of inflation on the real net return to saving. This distorts the allocation of lifetime consumption between early years and later years. Section 2 evaluates the deadweight loss that results from this distortion and from the associated effects on government revenue. Contrary to traditional welfare analysis, those revenue effects are important as soon as we recognize that any revenue gain from lower inflation permits a reduction in other distortionary taxes (and, similarly, any revenue loss from lower inflation requires an increase in some other distortionary tax.)

The inflation-induced reduction in the net return to financial assets also induces increased investment in owner-occupied residential real estate. Section 3 evaluates the deadweight loss that results from this effect of higher inflation.

In both cases, even the small reduction of inflation from two percent to zero can have a substantial effect on economic welfare because inflation increases the tax-induced distortions that

${ }^{7}$ In an earlier series of papers collected in Feldstein (1983) I examined the effect of the interaction of inflation and tax rules on tax liabilities, on equilibrium interest rates and asset prices, and on the accumulation of residential and nonresidential capital. None of those studies considered the welfare consequences of this interaction. 
would exist even with price stability. The deadweight loss associated with the shift from zero inflation to a two percent inflation rate is therefore not the traditional "small triangle" that would result from distorting a first-best equilibrium but is the much larger "trapezoid" that results from increasing a large initial distortion.

These adverse effects of the tax-inflation interaction could in principle be eliminated by indexing the tax system or by shifting from our current system of corporate and personal income taxes to a tax based only on consumption or labor income. As a practical matter, however, such tax reforms are extremely unlikely. Section 7 discusses some of the difficulties of shifting to an indexed tax system in which capital income and expenses are measured in real terms. Although such a shift has been advocated for at least two decades, there has been no legislation along those lines. It is significant, moreover, that no industrial country has fully (or even substantially) indexed its tax laws. More generally, the annual gains from shifting to price stability that are identified in this paper exceed the costs of the transition within a very few years. Even if one could be sure that the tax-inflation distortions would be eliminated ten years from now, the present value gain from price stability until then would exceed the cost of the inflation reduction.

The inflation-induced distortion in the lifetime allocation of consumption and in the allocation of spending between housing and other forms of consumption are only two of the many ways in which inflation imposes a cost on the economy. The most studied of these is the distortion in the demand for money. ${ }^{8}$ The interaction of inflation and tax rules also causes

${ }^{8}$ Bailey (1956) quantified the welfare loss of the reduction in the use of non-interestbearing money. This pioneering paper led to a very large literature of refinements and criticisms. Phelps (1973) argued that since seigniorage gains from inflation permit a reduction in other distortionary taxes some positive rate of inflation may be appropriate as part of an overall 
distortions in the mix of business investment ${ }^{9}$, in corporate finance ${ }^{10}$, and in the structure of individual portfolios ${ }^{11}$. Higher inflation rates may also imply more volatile inflation. ${ }^{12}$

Absolute price stability, as opposed to merely a lower rate of inflation, may bring a qualitatively different kind of benefit. A history of price stability may bring a "credibility bonus" in dealing with inflationary shocks. People who see persistent price level stability expect that it will persist in the future and that the government will respond to shocks in a way that maintains the price level. In contrast, if people see that the price level does not remain stable, they may have less confidence in the government's ability or willingness to respond to inflation shocks in a way that maintains the initial inflation rate. If so, any given positive demand shock

optimal tax structure. More precisely, it implies that the optimal rate of inflation would be greater than Milton Friedman's optimum of minus the marginal product of capital (Friedman, 1969).

In Feldstein (1979) I evaluated the tradeoff between the gains of reduced inflation and the costs of achieving that reduction in terms of the impact on the demand for money. That paper showed that a case can be made for a discount rate at which the permanent reduction in the "shoe leather" costs of distorted money demand exceeds the temporary cost of achieving lower inflation.

None of these studies takes into account the taxation of capital income and the interaction of inflation and tax rules.

${ }^{9}$ Because depreciation is not adjusted for inflation, an increase in the rate of inflation favors investment in inventories and short-lived equipment.

${ }^{10}$ The mixture of debt and equity finance is affected by the fact that nominal interest rates are deducted by business borrowers. Although portfolio investors are taxed on nominal interest incomes, their tax rates are typically lower than the tax rates of the borrowers. Much corporate debt is also held by untaxed entities like pension funds.

${ }^{11}$ The taxation of nominal interest and of nominal capital gains distorts the composition of household portfolios.

${ }^{12}$ Although the relation between the level and volatility of inflation has been established in a number of studies, it is not clear if this applies at the low levels of inflation that are the subject of the current research. 
may lead to more inflation and may require a greater output loss to reverse than would be true in an economy with a history of stable prices.

A stable price level is also a considerable convenience for anyone making financial decisions that involve future receipts and payments. While economists may be very comfortable with the process of converting nominal to real amounts, many people have a difficult time thinking about rates of change, real rates of interest, etc. Even among sophisticated institutional investors, it is remarkable how frequently projections of future returns are stated in nominal terms and based on past experience over periods with very different rates of inflation.

I will not attempt to evaluate all of these benefits of reducing inflation even though some of them may be as large as the improvements in the process of household capital accumulation that I do measure. The restricted set of benefits that I quantify substantially exceed (in present value at any plausible discount rate) the cost of getting to price stability from a low rate of inflation.

It would be wrong however to go from this calculation to the conclusion that the reduction in inflation increases net welfare without considering the possibility that there are also advantages of continuing a low rate of inflation rather than having price stability. The primary gain from inflation that has been identified in the literature is the seigniorage that the government enjoys from the higher rate of money creation. This seignorage revenue reduces the need for other distortionary taxes and therefore eliminates the deadweight loss that such taxes would entail. In addition, the real cost of servicing the national debt varies inversely with the rate of 
inflation. ${ }^{13}$ The value of these advantages of continuing the two percent inflation rate will be calculated explicitly in sections 4 and $5 .^{14}$

Table 1 summarizes all of the welfare changes that are discussed in the remaining sections of the paper. The specific assumptions and parameters values will be discussed there. With the parameter values that seem most likely, the overall total effect of reducing inflation from two percent to zero, shown in the lower right corner of the table, is to reduce the annual deadweight loss by between 0.63 percent of GDP and 1.01 percent of GDP.

The costs of reducing inflation and the value of lower inflation both depend on the institutional features of the economy, including the functioning of the labor and capital markets as well as the tax rules. The current analysis applies specifically to the United States in recent years but the method of analysis is clearly applicable to other countries and times.

\section{The Cost of Reducing Inflation}

Although it can be argued that an unambiguous commitment to price stability would cause the inflation rate to decline with no loss of output, my reading of the experience of countries like Germany and New Zealand suggests that even a long tradition of a commitment to low inflation or a contractual obligation with strong potential penalties is insufficient to achieve a

${ }^{13}$ A higher inflation rate reduces the real net cost of debt service because the equilibrium government bond rate rises point for point with inflation but the inflation premium is then subject to tax. The net nominal interest rate therefore rises less than point for point with inflation and the real net rate declines.

${ }^{14}$ There is also a recent theoretical literature on the potential advantages of inflation in inducing search that improves resource allocation in imperfectly competitive markets (e.g., Benabou, 1992). No attempt has been made to assess the possible magnitude of the benefit of this increased search. 
Table 1

The Net Welfare Effect of Reducing Inflation

from 2 Percent to Zero*

(Changes as percent of GDP)

Source of Change

Consumption

Timing

Housing

Demand

Money

Demand

Debt Service
Direct Effect of

$\underline{\text { Reduced Distortion }}$

Welfare Effect

of Revenue Change

$$
\begin{array}{ll}
\eta_{\mathrm{Sr}}=\mathbf{0 . 4} & \mathbf{1 . 0 2} \\
\eta_{\mathrm{Sr}}=0 & 0.73 \\
\eta_{\mathrm{Sr}}=1.0: & 1.44
\end{array}
$$

$\underline{\text { Total Effect }}$

$$
\underline{\lambda=0.4} \quad \underline{\lambda=1.5} \quad \underline{\lambda=0.4} \quad \underline{\lambda=1.5}
$$$$
-0.10-0.39
$$$$
0.92 \quad 0.63
$$$$
\begin{array}{ll}
-0.21 & -0.78
\end{array}
$$$$
0.52-0.05
$$$$
0.05 \quad 0.20
$$$$
1.49 \quad 1.64
$$

$1.49 \quad 1.64$

0.10

0.12

0.45

0.22

0.55

$$
0.02
$$

$-0.05$

$-0.19$

$-0.03$

$-0.17$

$$
\text { -- NA -- }
$$

$-0.10 \quad-0.38$

$-0.10 \quad-0.38$

\section{Totals}

$$
\begin{array}{llrr}
\eta_{\text {Sr }}=\mathbf{0 . 4} & \mathbf{1 . 1 4} & -\mathbf{0 . 1 3} & -\mathbf{0 . 5 1} \\
\eta_{\mathrm{Sr}}=0: & 0.85 & -0.24 & -0.90 \\
\eta_{\mathrm{Sr}}=1.0: & 1.56 & 0.02 & 0.08
\end{array}
$$

1.01

0.63

0.66

$-0.05$

1.58

1.64

NA: Not applicable

* A 2 percent inflation rate corresponds to a rise in the CPI at 4 percent a year. The welfare effects reported here are annual changes in welfare. 
painless reduction of inflation. For the purpose of this paper, I will therefore assume that the cost of reducing inflation can be inferred from the parameters of a short-run Phillips curve based on the experience of the United States over the past two decades.

Lawrence Ball (1995) provides a useful survey of previous empirical work in this area and new estimates of the cost of disinflation. More specifically, Ball estimates the cost of disinflation as the cumulative loss of GDP during the period when inflation is being reduced by raising the unemployment rate above the natural rate. He concludes that each percentage point reduction in the rate of inflation costs a cumulative output loss equal to between two percent and three percent of GDP. This implies that reducing inflation from two percent to zero has a onetime cost in the range of four percent of GDP to six percent of GDP.

This estimate makes no allowance for the offestting value of leisure, home production, and job search among the unemployed. It also makes no allowance for the possible persistent ("hysterisis") effects of job loss that might be caused by a loss of job specific human capital or more, generally, by an erosion of human capital during the period of unemployment. ${ }^{15}$

Rather than trying to make a more precise adjustment in the Ball measure of the cost of disinflation, I will assume the upper end of his range (six percent of GDP) and ask whether the present value of the gain in having price stability rather than two percent inflation exceeds six percent of the initial GDP. The analysis in this paper implies that the answer to that question is "yes" and would probably by "yes" even if the cost were substantially higher.

${ }^{15}$ The relatively short duration of cyclical unemployment spells in the United States implies that raising the unemployment to reduce inflation is unlikely to have a significant adverse effect on humal capital. 


\section{Inflation and the Intertemporal Allocation of Consumption}

Inflation reduces the real net of tax return to savers in many ways. At the corporate (or, more generally, the business) level, inflation reduces the value of depreciation allowances and therefore increases the effective tax rate. This lowers the rate of return that businesses can afford to pay for debt and equity capital. At the individual level, taxes levied on nominal capital gains and nominal interest also cause the effective tax rate to increase with the rate of inflation.

A reduction in the rate of return that individuals earn on their saving creates a welfare loss by distorting the allocation of consumption between the early years in life and the later years. Since the tax law creates such a distortion even when there is price stability, the extra distortion caused by inflation causes a first-order increased deadweight loss.

As I emphasized in an earlier paper (Feldstein, 1978), the deadweight loss that results from capital income taxes depends on the resulting distortion in the timing of consumption and not on the change in saving per se. Even if there is no change in saving, a tax-inflation induced decline in the rate of return implies a reduction in future consumption and therefore a deadweight loss. The current section calculates the general magnitude of the reduction in this welfare loss that results from lowering the rate of inflation from two percent to zero. ${ }^{16}$

To analyze the deadweight loss that results from a distortion of consumption over the individual life cycle, I consider a simple two-period model of individual consumption. Individuals receive income when they are young. They save a portion, S, of that income and

\footnotetext{
${ }^{16}$ Fischer (1981) used the framework of Feldstein (1978) to assess the deadweight loss caused by the effect of inflation on the return to savers. As the current analysis indicates, the problem is more complex than either Fischer or I recognized in those earlier studies.
} 
consume the rest. The savings are invested in a portfolio that earns a real net-of-tax return of $r$. At the end of $T$ years, the individuals retire and consume $C=(1+r)^{T} S$. In this framework, saving can be thought of as the expenditure (when young) to purchase retirement consumption at a price of $p=(1+r)^{-T}$

Even in the absence of inflation, the effect of the tax system is to reduce the rate of return on saving and therefore to increase the price of retirement consumption. As inflation increases, the price of retirement consumption increases further. Before looking at specific numerical values, I present graphically the welfare consequences of these changes in the price of retirement consumption. Figure 1 shows the individual's compensated demand for retirement consumption $\mathrm{C}$ as a function of the price of retirement consumption at the time that saving decisions are made (p).

Figure 1: $\quad$ Retirement Consumption

Price of

Retirement Consumption

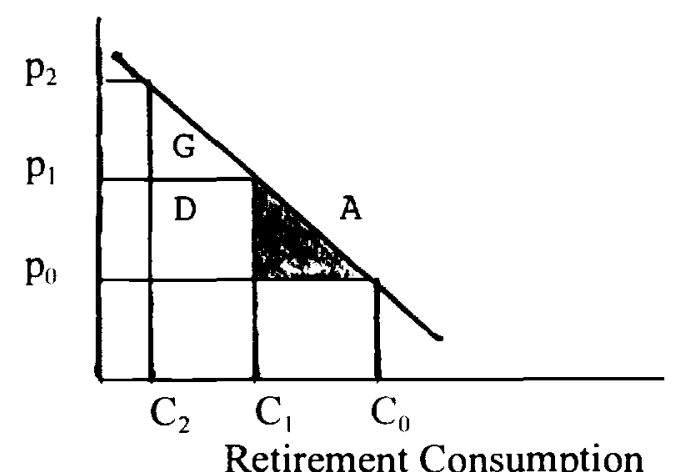

$\Delta D W L=\left(\mathrm{p}_{1}-\mathrm{p}_{0}\right)\left(\mathrm{C}_{1}-\mathrm{C}_{2}\right)+0.5\left(\mathrm{p}_{2}-\mathrm{p}_{1}\right)\left(\mathrm{C}_{1}-\mathrm{C}_{2}\right)$

$\Delta R E V=\left(p_{1}-p_{0}\right)\left(C_{1}-C_{2}\right)-\left(p_{2}-p_{1}\right) C_{2}$ 
In the absence of both inflation and taxes, the real rate of return implies a price of $\mathrm{p}_{0}$ and the individual chooses to save enough to generate retirement consumption of $\mathrm{C}_{0}$. With no inflation, the existing structure of capital income taxes at the business and individual levels raises the price of retirement consumption to $p_{1}$ and reduces retirement consumption to $C_{1}$. This increase in the price of retirement consumption causes the individual to incur the deadweight loss shown as the shaded area A, i.e., the amount that the individual would have to be compensated for the rise in the price of retirement consumption in order to remain at the same initial utility level exceeds the revenue collected by the government by an amount equal to the area $\mathrm{A}$. Raising the rate of inflation from zero to two percent increases the price of retirement consumption to $\mathrm{p}_{2}$ and reduces retirement consumption to $C_{2}$. The deadweight loss now increases by the trapezoidal area $C+D$ $=\left(p_{1}-p_{0}\right)\left(C_{1}-C_{2}\right)+0.5\left(p_{2}-p_{1}\right)\left(C_{1}-C_{2}\right)$.

The revenue effect of such tax changes are generally ignored in welfare analyses because it is assumed that any loss or gain in revenue can be offset by a lump sum tax or transfer. More realistically, however, we must recognize that offsetting a revenue change due to a change in inflation involves distortionary taxes and therefore each dollar of revenue gain or loss has an additional effect on overall welfare. The net welfare effect of reducing the inflation rate from two percent to zero is therefore the combination of the traditional welfare gain (the trapezoid $\mathrm{C}+$ D) and the welfare gain (loss) that results from an increase (decrease) in tax revenue. I begin by evaluating the traditional welfare gain and then calculate the additional welfare effect of the changes in tax revenue.

\subsection{The Welfare Gain from Reduced Intertemporal Distortion}

The annual welfare gain from reduced intertemporal distortion is $\left(\mathrm{p}_{1}-\mathrm{p}_{0}\right)\left(\mathrm{C}_{1}-\mathrm{C}_{2}\right)+$ 
$0.5\left(\mathrm{p}_{2}-\mathrm{p}_{1}\right)\left(\mathrm{C}_{1}-\mathrm{C}_{2}\right)=\left[\left(\mathrm{p}_{1}-\mathrm{p}_{0}\right)+0.5\left(\mathrm{p}_{2}-\mathrm{p}_{1}\right)\right]\left(\mathrm{C}_{1}-\mathrm{C}_{2}\right)$ The change in retirement consumption can be approximated as $C_{1}-C_{2}=(d C / d p)\left(p_{1}-p_{2}\right)=$ $\mathrm{C}_{2}\left(\mathrm{p}_{2} / \mathrm{C}_{2}\right)(\mathrm{dC} / \mathrm{dp})\left(\mathrm{p}_{1}-\mathrm{p}_{2}\right) / \mathrm{p}_{2}=\mathrm{C}_{2} \varepsilon_{\mathrm{Cp}}\left[\left(\mathrm{p}_{1}-\mathrm{p}_{2}\right) / \mathrm{p}_{2}\right]$ where $\varepsilon_{\mathrm{Cp}}<0$ is the compensated elasticity of retirement consumption with respect to its price (as evaluated at the observed initial inflation rate of two percent). Thus the gain from reduced intertemporal distortion is: ${ }^{17}$

$$
\begin{aligned}
\mathrm{G}_{1} & =\left[\left(\mathrm{p}_{1}-\mathrm{p}_{0}\right)+0.5\left(\mathrm{p}_{2}-\mathrm{p}_{1}\right)\right] \mathrm{C}_{2} \varepsilon_{\mathrm{Cp}}\left[\left(\mathrm{p}_{1}-\mathrm{p}_{2}\right) / \mathrm{p}_{2}\right] \\
& =\left[\left(\mathrm{p}_{1}-\mathrm{p}_{0}\right) / \mathrm{p}_{2}+0.5\left(\mathrm{p}_{2}-\mathrm{p}_{1}\right) / \mathrm{p}_{2}\right] \mathrm{p}_{2} \mathrm{C}_{2} \varepsilon_{\mathrm{Cp}}\left[\left(\mathrm{p}_{1}-\mathrm{p}_{2}\right) / \mathrm{p}_{2}\right]
\end{aligned}
$$

Note that if there were no tax induced distortion when the inflation rate is zero $\left(p_{1}=p_{0}\right), G_{1}$ would simplify to the traditional triangle formula for the deadweight loss of a price change from $\mathrm{p}_{1}$ to $\mathrm{p}_{2}$.

To move from equation 1 to observable magnitudes, note that the compensated elasticity $\varepsilon_{C_{p}}$ can be written in terms of the corresponding uncompensated elasticity $\eta_{C_{p}}$ and the propensity to save out of exogenous income $\sigma$ as ${ }^{18}$

$$
\varepsilon_{\mathrm{Cp}}=\eta_{\mathrm{Cp}}+\sigma
$$

Moreover, since saving and retirement consumption are related by $S=p C$, the elasticity of retirement consumption with respect to its price and the elasticity of saving with respect to the

${ }^{17}$ This could be stated as the difference between the areas of the two deadweight loss triangles corresponding to prices $p_{1}$ and $p_{2}$ but the expression used here presents a better approximation.

${ }^{18}$ This follows from the usual Slutsky decomposition: $\mathrm{dC} / \mathrm{dp}=\{\mathrm{dC} / \mathrm{dp}\}_{\text {сом }}-\mathrm{C}(\mathrm{dC} / \mathrm{dy})$ where $\mathrm{dC} / \mathrm{dy}$ is the increase in retirement consumption induced by an increase in exogenous income. Multiplying each term by $\mathrm{p} / \mathrm{C}$ and noting that $\mathrm{p}(\mathrm{dC} / \mathrm{dy})=\mathrm{dpC} / \mathrm{dy}=\mathrm{dS} / \mathrm{dy}=\sigma$ yields equation (2). 
price of retirement consumption are related by $\eta_{C p}=\eta_{S p}-1$. Thus

$$
\varepsilon_{\mathrm{Cp}}=\eta_{\mathrm{Sp}}+\sigma-1
$$

and

$$
\mathrm{G}_{1}=\left[\left(\mathrm{p}_{1}-\mathrm{p}_{0}\right) / \mathrm{p}_{2}+0.5\left(\mathrm{p}_{2}-\mathrm{p}_{4}\right) / \mathrm{p}_{2}\right]\left[\left(\mathrm{p}_{2}-\mathrm{p}_{1}\right) / \mathrm{p}_{2}\right] \mathrm{S}_{2}\left(1-\eta_{\mathrm{Sp}}-\sigma\right)
$$

where $\mathrm{S}_{2}=\mathrm{p}_{2} \mathrm{C}_{2}$, the gross saving of individuals at the early stage of the life cycle.

To evaluate equation 4 requires numerical estimates of the price of future consumption at different inflation rates and without any tax, as well as estimates of gross saving, of the saving elasticity and of the propensity to save out of exogenous income.

\subsubsection{Inflation Rates and the Price of Retirement Consumption}

To calculate the price of retirement consumption, I assume the time interval between saving and consumption is 30 years; e.g., the individual saves on average at age February 5, 1996 and then dissaves at age 70. Thus $p=(1+r)^{-30}$ where the value of $r$ depends on the tax system and the rate of inflation. From 1960 through 1994, the pretax real return to capital in the U.S. nonfinancial corporate sector averaged 9.2 percent. ${ }^{19}$ Ignoring general equilibrium effects and taking this as the measure of the discrete-time return per year that would prevail in the absence of taxes implies that the corresponding price of retirement consumption is $\mathrm{p}_{0}=(1.092)^{-(30)}=0.071$.

Taxes paid by corporations to federal, state and local governments equaled about 41 percent of the total pretax return during this period, leaving a real net return before personal taxes

${ }^{19}$ This 9.2 percent is the ratio of profits before all taxes (including property taxes as well as income taxes) plus real net interest payments to the replacement value of the capital stock. Feldstein, Poterba and Dicks-Mireaux (1983) describe the method of calculation and Rippe (1995) brings the calculation up to date. Excluding the property taxes would reduce this return by about 0.7 percentage points; see Poterba and Samwick (1995). 
of 5.4 percent (Rippe, 1995). I will take this yield difference as an indication of the combined effects of taxes and inflation at 2 percent (i.e., measured inflation at 4 percent) even though tax rules, tax rates and inflation varied over this 35 year interval. ${ }^{20}$ The net of tax rate of return depends not only on the tax at the corporate level but also on the taxes that individuals pay on that after-corporate-tax return, including the taxes on interest income, dividends and capital gains. The effective marginal tax rate depends on the form of the income and on the tax status of the individual. I will summarize all of this by assuming a marginal "individual" tax rate of 25 percent. This reduces the net return from 5.4 percent to 4.05 percent. The analysis of the gain from reducing the equilibrium rate of inflation is not sensitive to the precise level of this return or the precise difference between it and the 9.2 percent pretax return since our concern is with the effect of a difference in inflation rates on effective tax rates. Similarly, the precise level of the initial effective tax rate is not important to the current calculations since our concern is with the change in the effective tax rate that occurs as a result of the change in the equilibrium rate of inflation. $^{21}$ The price of retirement consumption that corresponds to this net return of 4.05 percent is $\mathrm{p}_{2}=(1.0405)^{-30}=0.304$ where the subscript 2 on the price indicates that this represents the price at an inflation rate of two percent.

Reducing the equilibrium inflation rate from two percent to zero lowers the effective tax rate at both the corporate and individual levels. At the corporate level, changes in the equilibrium inflation rate alter the effective tax rate by changing the value of depreciation

${ }^{20}$ The average rate of measured inflation during this period was actually 4.7 percent, implying an average "true" inflation rate of 2.7 percent.

${ }^{21}$ Some explicit sensitivity calculations are presented below. 
allowances and by changing the value of the deduction of interest payments. Because the depreciation schedule that is allowed for calculating taxable profits is defined in nominal terms, a higher rate of inflation reduces the present value of the depreciation and thereby increases the effective tax rate. ${ }^{22}$ Auerbach (1978) showed that this relation can be approximated by a rule of thumb that increases taxable profits by 0.57 percentage points for each percentage point of inflation. With a marginal corporate income tax rate of 35 percent, a two percentage point decline in inflation raises the net of tax return through this channel by $0.35(0.57)(0.02)=0.0040$ or 0.40 percentage points. ${ }^{23}$

The interaction of the interest deduction and inflation moves the after tax yield in the opposite direction. If each percentage point of inflation raises the nominal corporate borrowing rate by one percentage point, ${ }^{24}$ the real pretax cost of borrowing is unchanged but the corporation

\footnotetext{
${ }^{22}$ See Feldstein, Green and Sheshinski (1978) for an analytic discussion of the effect of inflation on the value of depreciation allowances.

${ }^{23}$ It might be argued that Congress changes depreciation rates in response to changes in inflation in order to keep the real present value of depreciation allowances unchanged. But although Congress did enact more rapid depreciation schedules in the early 1980s, the decline in inflation since that time has not been offset by lengthening depreciation schedules and has resulted in a reduction in the effective rate of corporate income taxes.

${ }^{24}$ This famous Irving Fisher hypothesis of a constant real interest rate is far from inevitable in an economy with a complex non-neutral tax structure. For example, if the only nonneutrality were the ability of corporations to deduct nominal interest payments and all investment were financed by debt at the margin, the nominal interest rate would rise by $1 /(1-\tau)$ times the change in inflation where $\tau$ is the statutory corporate tax rate. This effect is diminished however by the combination of historic cost depreciation, equity finance, international capital flows and the tax rules at the level of the individual. (See Feldstein 1983, 1995a and Hartman, 1979) Despite the theoretical ambiguity, the evidence suggests that these various tax rules and investor behavior interact in practice in the United States to keep the real pretax rate of interest approximately unchanged when the rate of inflation changes; see Mishkin (1992).
} 
gets an additional deduction in calculating taxable income. With a typical debt-capital ratio of forty percent and a statutory corporate tax rate of 35 percent, a two percent decline in inflation raises the effective tax rate by $0.35(0.40)(0.02)=0.0028$ or 0.28 percentage points.

The net effect of going from a two percent inflation rate to price stability is therefore to raise the rate of return after corporate taxes by 0.12 percentage points, from the 5.40 percent calculated above to 5.52 percent. $^{25}$

Consider next how the lower inflation rate affects the taxes at the individual level. Applying the 25 percent tax rate to the 5.52 percent return net of the corporate tax implies a net yield of 4.14 percent, an increase of 0.09 percentage points in net yield to the individual because of the changes in taxation at the corporate level. In addition, because individual income taxes are levied on nominal interest payments and nominal capital gains, a reduction in the rate of inflation further reduces the effective tax rate and raises the real after-tax rate of return.

The portion of this relation that is associated with the taxation of nominal interest at the level of the individual can be approximated in a way that parallels the effect at the corporate level. If each percentage point of inflation raises the nominal interest rate by one percentage point, the individual investors' real pretax return on debt is unchanged but the after tax return falls by the product of the statutory marginal tax rate and the change in inflation. Assuming the same forty percent debt share at the individual level as I assumed for the corporate capital stock ${ }^{26}$

\footnotetext{
${ }^{25}$ Note that although the margin of uncertainty about the 5.5 percent exceeds the calculated change in return of 0.12 percent, the conclusions of the current analysis are not sensitive to the precise level of the initial 5.5 percent rate of return.

${ }^{26}$ This ignores individual investments in government debt. Bank deposits backed by noncorporate bank assets (e.g., home mortgages ) can be ignored as being within the household 
and a 25 percent weighted average individual marginal tax rate implies that a two percent decline in inflation lowers the effective tax rate by $0.25(0.40)(0.02)=0.0020$ or 0.20 percentage points.

Although the effective tax rate on the dividend return to the equity portion of individual capital ownership is not affected by inflation (except, of course, at the corporate level), a higher rate of inflation increases the taxation of capital gains. Although capital gains are now taxed at the same rate as other investment income (up to a maximum capital gain rate of 28 percent at the federal level), the effective tax rate is lower because the tax is only levied when the stock is sold. As an approximation, I will therefore assume a 10 percent effective marginal tax rate on capital gains. In equilibrium, each percentage point increase in the price level raises the nominal value of the capital stock by one percentage point. Since the nominal value of the liabilities remains unchanged, the nominal value of the equity rises by $1 /(1-b)$ percentage points where $b$ is the debt to capital ratio. With $b=0.4$ and an effective marginal tax on nominal capital gains of $\theta_{g}=0.1$, a two percentage point decline in the rate of inflation raises the real after tax rate of return on equity by $\theta_{\mathrm{g}}[1 /(1-\mathrm{b})] \mathrm{d} \pi=0.0033$ or 0.33 percentage points. However, since equity represents only 60 percent of the individuals' portfolio, the lower effective capital gains tax raises the overall rate of return by only 60 percent of this 0.33 percentage points or 0.20 percentage points. ${ }^{27}$

Combining the debt and capital gains effects implies that reducing the inflation rate by

sector.

${ }^{27}$ The assumption that the share of debt in the individuals' portfolio is the same as the share of debt in corporate capital causes the $1 /(1-b)$ term to drop out of the calculation. More generally, the effect of inflation on the individuals' rate of return depends on the difference between the shares of debt in corporate capital and in the individuals portfolios. 
two percentage points reduces the effective tax rate at the individual investor level by the equivalent of 0.40 percentage points. The real net return to the individual saver is thus 4.54 percent, up 0.49 percentage points from the return when the inflation rate is two percentage points higher. The implied price of retirement consumption is $p_{1}=(1.0454)^{-30}=0.264$.

Substituting these values for the price of retirement consumption into equation 4 implies ${ }^{28}$

$$
\mathrm{G}_{1}=0.092 \mathrm{~S}_{2}\left(1-\eta_{\mathrm{Sp}}-\sigma\right)
$$

\subsubsection{The Saving Rate and Saving Behavior}

The value of $S_{2}$ in equation 5 represents the saving during preretirement years at the existing rate of inflation. This is, of course, different from the national income account measure of personal saving since personal saving is the difference between the saving of the younger savers and the dissaving of retired dissavers.

One strategy for approximating the value of $S_{2}$ is to use the relation between $S_{2}$ and the national income account measure of personal saving in an economy in steady state growth. In the simple overlapping generations model with saving proportional to income, saving grows at a rate of $n+g$ where $n$ is the rate of population growth and $g$ is the growth in per capita wages. This implies that the saving of the young savers is $(1+n+g)^{T}$ times the dissaving of the older

\footnotetext{
${ }^{28}$ To test the sensitivity of this result to the assumption about the pretax return and the effective corporate tax rate, I recalculated the retirement consumption prices using alternatives to the assumed values of 9.2 percent for the pretax return and 0.41 for the combined effective corporate tax rate. Raising the pretax rate of return from 9.2 percent to 10 percent only changed the deadweight loss value in equation 5 from 0.092 to 0.096 ; lowering the pretax rate of return from 9.2 percent to 8.4 percent lowered the deadweight loss value to 0.090 . Increasing the effective corporate tax rate from 0.41 to 0.50 with a pretax return of 9.2 only shifted the deadweight loss value in equation 5 from 0.092 to 0.096 . These calculations confirm that the effect of changing the equilibrium inflation rate is not sensitive to the precise values assumed for the pretax rate of return and the effective baseline tax rate.
} 
dissavers. $^{29}$

Thus net personal saving $\left(S_{N}\right)$ in the economy is related to the saving of the young $\left(S_{y}\right)$ according to:

$$
S_{N}=S_{y}-(1+n+g)^{-T} S_{y}
$$

The value of $S_{2}$ that we need is conceptually equivalent to $S_{y}$. Real aggregate wage income grew in the United States at a rate of 2.6 percent between 1960 and 1994 . Using $\mathrm{n}+\mathrm{g}=0.026$ and $\mathrm{T}=30$ implies that $\mathrm{S}_{\mathrm{y}}=1.86 \mathrm{~S}_{\mathrm{N}}$. If we take personal saving to be approximately 5 percent of GDP, this implies that $\mathrm{S}_{2}=0.09$ GDP. ${ }^{30}$

If the propensity to consume out of exogenous income $(\sigma)$ is the same as the propensity to consume out of wage income, $\sigma=\mathrm{S}_{2} /(\alpha *$ GDP) where $\alpha$ is the share of wages in GDP. With $\alpha=0.75$, this implies $\sigma=0.12$.

The final term to be evaluated in order to calculate the welfare gain described in equation 5 is the elasticity of saving with respect to the price of retirement consumption. Since the price of retirement consumption is given by $p=(1+r)^{-T}$, the uncompensated elasticity of savings with respect to the price of retirement consumption can be restated as an elasticity with respect to the real rate of return: $\eta_{\mathrm{Sr}}=-\mathrm{rT} \eta_{\mathrm{sp}} /(1+\mathrm{r})$. Thus equation 5 becomes

$$
\mathrm{G}_{1}=0.092 \mathrm{~S}_{2}\left(1+(1+\mathrm{r}) \eta_{\mathrm{Sr}} / \mathrm{rT}-\sigma\right) \text {. }
$$

${ }^{29}$ Note that the spending of the older retirees includes both the dissaving of their earlier saving and the income that they have earned on their saving. Net personal saving is only the difference between the saving of the savers and the dissaving of the dissavers.

${ }^{30}$ This framework can be extended to recognize that the length of the work period is roughly twice as long as the length of the retirement period without appreciably changing this result. 
Estimating the elasticity of saving with respect to the real net rate of return has proven to be very difficult because of the problems involved in measuring changes in expected real net-oftax returns and in holding constant in the time series data the other factors that affect savings. The large literature on this subject generally finds that a higher real rate of return either raises the saving rate or has no affect at all. ${ }^{31}$ In their classic study of the welfare costs of U.S. taxes, Ballard, Shoven and Whalley (1985) assumed a saving elasticity of $\eta_{\mathrm{Sr}}=0.40$. I will take this as the benchmark value for the current study. In this case, equation 7 implies (with $r=0.04$ )

$$
\begin{aligned}
& \mathrm{G}_{1}=0.092 \mathrm{~S}_{2}\left(1+(1+\mathrm{r}) \eta_{\mathrm{sr}} / \mathrm{rT}-\sigma\right) . \\
& =0.092(0.09)(1+0.42 / 1.2-0.12) \mathrm{GDP}=0.0102 \mathrm{GDP},
\end{aligned}
$$

The annual gain from reduced distortion of consumption is equal to 1.02 percent of GDP. This figure is shown in the first row of Table 1.

To assess the sensitivity of this estimate to the value of $\eta_{\mathrm{Sr}}$, I will also examine two other values. The limiting case in which changes in real interest rates have no effect on saving, i.e., that $\eta_{\mathrm{sr}}=0$, implies: ${ }^{32}$

$$
\begin{aligned}
& \mathrm{G}_{1}=0.092 \mathrm{~S}_{2}\left(1+(1+\mathrm{r}) \eta_{\mathrm{Sr}_{\mathrm{r}}} / \mathrm{rT}-\sigma\right) . \\
& =0.092(0.09)(1-.12) \mathrm{GDP}=0.0073 \mathrm{GDP},
\end{aligned}
$$

i.e., an annual welfare gain equal to 0.73 percentage points of GDP.

${ }^{3}$ See among others Blinder (1975), Boskin (1978), Evans (1983), Feldstein (1995b), Hall (1987), Makin (1987), Mankiw (1987) and Wright (1969).

${ }^{32}$ This is a limiting case in the sense that empirical estimates of $\eta_{\mathrm{Sr}}$ are almost always positive. In theory of course it is possible that $\eta_{\mathrm{Sr}}<0$. 
If we assume instead that $\eta_{S_{r}}=1.0$, i.e., that increasing the real rate of return from 4.0 percent to 4.5 percent (the estimated effect of dropping the inflation rate from two percent to zero) raises the saving rate 9 percent to 10.1 percent, the welfare gain is $G_{1}=0.0144$ GDP.

These calculations suggest that the traditional welfare effect on the timing of consumption of reducing the inflation rate from two percent to zero is probably bounded between 0.73 percentage points of GDP and 1.44 percent of GDP. These figures are shown in the second and third rows of Table 1.

\subsection{The Revenue Effects of a Lower Inflation Rate Causing a Lower Effective Tax on Investment Income}

As I noted earlier, the traditional assumption in welfare calculations and the one that is implicit in the calculation of section 2.1 , is that any revenue effect can be offset by lump sum taxes and transfers. When this is not true, as it clearly is not in the U.S. economy, an increase in tax revenue has a further welfare advantage because it permits reduction in other distortionary taxes while a loss of tax revenue implies a welfare cost of using other distortionary taxes to replace the lost revenue. The present section calculates the effect on tax revenue paid by the initial generation of having price stability rather than a two percent inflation rate and discusses the corresponding effect on economic welfare.

Reducing the equilibrium rate of inflation raises the real return to savers and therefore reduces the price of retirement consumption. The effect of this on government revenue depends on the change in retirement consumption implied by the compensated demand curve. ${ }^{33}$ At the

\footnotetext{
${ }^{33}$ The compensated demand curve is used because, for taxpayers as a whole, other taxes are adjusted to keep total revenue constant. Although this is not exact compensation for each taxpayer, the compensated demand curve is much more nearly appropriate than the
} 
initial level of retirement consumption, reducing the price of future consumption from $p_{2}$ to $p_{1}$ reduces revenue (evaluated as of the initial time) by $\left(p_{2}-p_{1}\right) C_{2}$. If the fall in the price of retirement consumption causes retirement consumption to increase from $C_{2}$ to $C_{1}$, the government collects additional revenue equal to $\left(\mathrm{p}_{1}-\mathrm{p}_{0}\right)\left(\mathrm{C}_{1}-\mathrm{C}_{2}\right)$. Even if $\mathrm{C}_{2}<\mathrm{C}_{1}$, the overall net effect on revenue, $\left(p_{1}-p_{0}\right)\left(C_{1}-C_{2}\right)-\left(p_{2}-p_{1}\right) C_{2}$, can in theory be either positive or negative.

In the present case, the change in revenue can be calculated as:

$$
\begin{aligned}
\mathrm{dREV} & =\left(\mathrm{p}_{1}-\mathrm{p}_{0}\right)\left(\mathrm{C}_{1}-\mathrm{C}_{2}\right)-\left(\mathrm{p}_{2}-\mathrm{p}_{1}\right) \mathrm{C}_{2} \\
& =\left(\mathrm{p}_{1}-\mathrm{p}_{0}\right)(\mathrm{dC} / \mathrm{dp})\left(\mathrm{p}_{1}-\mathrm{p}_{2}\right)-\left(\mathrm{p}_{2}-\mathrm{p}_{1}\right) \mathrm{C}_{2} \\
& =\left(\mathrm{p}_{1}-\mathrm{p}_{0}\right)\left(\mathrm{p}_{1}-\mathrm{p}_{2}\right)(\mathrm{dC} / \mathrm{dp})\left(\mathrm{p}_{2} / \mathrm{C}_{2}\right)\left(\mathrm{C}_{2} / \mathrm{p}_{2}\right)-\left(\mathrm{p}_{2}-\mathrm{p}_{1}\right) \mathrm{C}_{2} \\
& =\left(\mathrm{p}_{1}-\mathrm{p}_{0}\right)\left(\mathrm{p}_{1}-\mathrm{p}_{2}\right) \varepsilon_{\mathrm{Cp}}\left(\mathrm{C}_{2} / \mathrm{p}_{2}\right)-\left(\mathrm{p}_{2}-\mathrm{p}_{1}\right) \mathrm{C}_{2}
\end{aligned}
$$

Replacing $\mathrm{p}_{2} \mathrm{C}_{2}$ by $S_{2}$ and recalling from equation (3) that $\varepsilon_{\mathrm{Cp}}=\eta_{\mathrm{sp}}+\sigma-1$ yields

$$
\left.\left.d R E V=S_{2}\left\{\left[\left(p_{1}-p_{0}\right) / p_{2}\right)\right]\left[\left(p_{2}-p_{1}\right) / p_{2}\right)\right]\left(1-\eta_{S_{p}}-\sigma\right)-\left(p_{2}-p_{1}\right) / p_{2}\right\}
$$

Substituting the prices derived in the previous section $\left(\mathrm{p}_{0}=0.071 ; \mathrm{p}_{1}=0.264 ;\right.$ and $\left.\mathrm{p}_{2}=0.304\right)$ implies

$$
\begin{aligned}
\mathrm{dREV} & =S_{2}\left\{0.0836\left(1-\eta_{\mathrm{Sp}_{\mathrm{p}}}-\sigma\right)-0.1316\right\} \\
& =\mathrm{S}_{2}\left\{0.0836\left(1+(1+\mathrm{r}) \eta_{\mathrm{Sr}} / \mathrm{rT}-\sigma\right)-0.1316\right\}
\end{aligned}
$$

With $\sigma=0.12$ (as derived in section 2.1.3), the benchmark case of $\eta_{\mathrm{Sr}}=0.4$ implies dREV $=-$ $0.029 \mathrm{~S}_{2}$ or, with $\mathrm{S}_{2}=0.09 \mathrm{GDP}$ as derived above, $\mathrm{dREV}=-0.0026 \mathrm{GDP}$.

uncompensated demand curve. 
The limiting case of $\eta_{\mathrm{Sr}}=0$ implies dREV $=-0.0052 \mathrm{GDP}$ while $\eta_{\mathrm{Sr}}=1.0$ implies $\mathrm{d} \operatorname{REV}=0.0013 \mathrm{GDP}$.

Thus, depending on the uncompensated elasticity of saving with respect to the rate of interest, the revenue effect of shifting from two percent inflation to price stability can be either negative or positive.

\subsection{The Welfare Gain from the Effects of Reduced Inflation on Consumption Timing}

We can now combine the traditional welfare gain $\left(G_{1}\right.$ of equations 8 and 9$)$ with the welfare consequences of the revenue change (dREV of equations 11 and 12). If each dollar of revenue that must be raised from other taxes involves a deadweight loss of $\lambda$, the net welfare gain of shifting from two percent inflation to price stability is

$$
\mathrm{G}_{2}=[0.0102-0.0026 \lambda] \mathrm{GDP} \text { if } \eta_{\mathrm{Sr}}=0.4
$$

Similarly,

$$
\mathrm{G}_{2}=[0.0073-0.0052 \lambda] \mathrm{GDP} \text { if } \eta_{\mathrm{Sr}}=0
$$

and

$$
\mathrm{G}_{2}=[0.0144+0.0013 \lambda] \mathrm{GDP} \text { if } \eta_{\mathrm{Sr}}=1.0
$$

The value of $\lambda$ depends on the change in taxes that is used to adjust to changes in revenue. Ballard, Shoven and Whalley (1985) used a computable general equilibrium model to calculate the effect of increasing all taxes in the same proportion and concluded that the deadweight loss per dollar of revenue was between 30 cents and 55 cents, depending on parameter assumptions. I will represent this range by $\lambda=0.40$. Using this implies that the net welfare gain of reducing inflation from two percent to zero equals 0.92 percent of GDP in the 
benchmark case of $\eta_{\mathrm{s}_{\mathrm{r}}}=0.4$. The welfare effect of reduced revenue (-0.10 percent of GDP) is shown in the second column of Table 1 and the combined welfare effect of 0.92 percent of GDP is shown in column 4 of Table 1 .

In the other two limiting cases, the net welfare gain corresponding to $\lambda=0.4$ are 0.52 percent of GDP with $\eta_{\mathrm{Sr}_{\mathrm{r}}}=0$ and 1.49 percent of GDP with $\eta_{\mathrm{Sr}}=1.0$. These are shown in the second and third rows of column 4 of Table 1.

The analysis of Ballard et. al.(1985) estimates the deadweight loss of higher tax rates on the basis of the distortion in labor supply and saving. No account is taken of the effect of higher tax rates on tax avoidance through spending on deductible items or receiving income in nontaxable forms (fringe benefits, nicer working conditions, etc.). In a recent paper (Feldstein, 1995c), I showed that these forms of tax avoidance as well as the traditional reduction of earned income can be included in the calculation of the deadweight loss of changes in income tax rates by using the compensated elasticity of taxable income with respect to the net of tax rate. Based on an analysis of the experience of high income taxpayers before and after the 1986 tax rate reductions, I estimated that elasticity to be 1.04 (Feldstein, 1995d). Using this elasticity in the NBER TAXSIM model, I then estimated that a ten percent increase in all individual income tax rates would cause a deadweight loss of about $\$ 44$ billion at 1994 income levels; since the corresponding revenue increase would be $\$ 21$ billion, the implied value of $\lambda$ is $\lambda=2.06$.

A subsequent study (Feldstein and Feenberg, 1995) based on the 1993 tax rate increases suggests a somewhat smaller compensated elasticity of about 0.83 instead of the 1.04 value derived in the earlier study. Although this difference may reflect the fact that the 1993 study is 
based on the experience during the first year only, I will be conservative and assume a lower deadweight loss value of $\lambda=1.5$.

With $\lambda=1.5$, equations $13 \mathrm{a}$ through $13 \mathrm{c}$ imply a wider range of welfare gain estimates: reducing inflation from two percent to zero increases the annual level of welfare by 0.63 percent of GDP in the benchmark case of $\eta_{\mathrm{Sr}}=0.4$. With $\eta_{\mathrm{Sr}}=0$, the net effect is a very small loss of 0.05 percent of GDP while with $\eta_{\mathrm{Sr}_{\mathrm{r}}}=1.0$ the net effect is a substantial gain of 1.64 percent of GDP. These values are shown in columns three and five of Table 1.

These are of course just the annual effects of inflation on savers' intertemporal allocation of consumption. Before turning to the other effects of inflation, it is useful to say a brief word about nonsavers.

\section{$2.4 \quad$ Nonsavers}

A striking fact about American households is that a large fraction of households have no financial assets at all. Almost 20 percent of U.S. households with heads aged 55 to 64 had no net financial assets at all in 1991 and 50 percent of such households had assets under $\$ 8,300$; these figures exclude mortgage obligations from financial liabilities.

The absence of substantial saving does not imply that individuals are irrational or unconcerned with the need to finance retirement consumption. Since Social Security benefits replace more than two-thirds of after tax income for a worker who has had median lifetime earnings and many employees can anticipate private pension payments in addition to Social Security, the absence of additional financial assets may be consistent with rational life-cycle 
behavior. For these individuals, zero saving represents a constrained optimum. ${ }^{34}$

In the presence of private pensions and social security, the shift from low inflation to price stability may cause some of these households to save and that increase in saving may increase their welfare and raise total tax revenue. Since the welfare gain calculated that I reported earlier in this section is proportional to the amount of saving by pre-retirement workers, it ignores the potential gain to current nonsavers.

Although the large number of nonsavers and their high aggregate income imply that this effect could be important, I have no way to judge how the increased rate of return would actually affect behavior. I therefore leave this out of the calculations, only noting that it implies that my estimate of the gain from lower inflation is to this extent undervalued.

\section{Inflationary Distortion of the Demand for Owner Occupied Housing}

Owner occupied housing receives special treatment under the personal income tax. Mortgage interest payments and local property taxes are deducted but no tax is imposed on the implicit "rental" return on the capital invested in the property. This treatment would induce too much consumption of housing services even in the absence of inflation.

Inflation reduces the cost of owner occupied housing services in two ways. The one that

\footnotetext{
${ }^{34}$ The observed small financial balances of such individuals may be precautionary balances or merely transitory funds that will soon be spent. It would be desirable to refine the calculations of this section to recognize that some of the annual national income account savings are for precautionary purposes. Since there is no satisfactory closed form expression relating the demand for precautionary saving to the rate of interest, I have not pursued that calculation further.
}

${ }^{35}$ This section benefits from the analysis in Poterba (1984 and 1992) but differs from the framework used there in a number of ways. 
has been the focus of the literature on this subject (e.g., Rosen, 1985) is the increased deduction of the nominal mortgage interest payments. Since the real rate remains unchanged while the tax deduction increases, the subsidy increases and the net cost of housing services declines. In addition, inflation increases the demand for owner occupied housing by reducing the return on investments in the debt and equity of corporations.

Reducing the rate of inflation therefore reduces the deadweight loss that results from excessive demand for housing services. In addition, a lower inflation rate reduces the loss of tax revenue; if raising revenue involves a deadweight loss, this reduction in the loss of tax revenue to the housing subsidy provides an additional welfare gain.

\subsection{The Welfare Gain from Reduced Distortion of Housing Consumption}

In the absence of taxes, the implied rental cost of housing per dollar of housing capital $\left(R_{6}\right)$ reflects the opportunity cost of the resources:

$$
\mathrm{R}_{0}=\rho+m+\delta
$$

where $\rho$ is the real return on capital in the nonhousing sector, $m$ is the cost of maintenance per dollar of housing capital and $\delta$ is the rate of depreciation. With $\rho=0.092$ (the average pretax real rate of return on capital in the nonfinancial corporate sector between 1960 and 1994), $\mathrm{m}=$

0.02 and $\delta=0.02,{ }^{36} R_{0}=0.132$; the rental cost of owner occupied housing would be 13.2 cents per dollar of housing capital.

Consider in contrast the corresponding implied rental cost per dollar of housing capital under the existing tax rules for a couple who itemize their tax return:

\footnotetext{
${ }^{36}$ These values of $\mathrm{m}$ and $\delta$ are from Poterba (1992).
} 


$$
R I=\mu(1-\theta) i_{m}+(1-\mu)\left(r_{n}+\pi\right)+(1-\theta) \tau_{p}+m+\delta-\pi
$$

where $\mathrm{RI}$ indicates that it is the rental cost of an itemizer; $\mu$ is the ratio of the mortgage to the value of the house; $\theta$ is the marginal income tax rate; $i_{m}$ is the interest rate paid on the mortgage; $r_{n}$ is the real net rate of return available on portfolio investments; $\tau_{p}$ is the rate of property tax $;{ }^{37} \mathrm{~m}$ and $\delta$ are as defined above; and $\pi$ is the rate of inflation (assumed to be the same for goods in general and for house prices). This equation says that the annual cost of owning a dollar's worth of housing is the sum of the net of tax mortgage interest payments $\mu$ [ $\left.(1-\theta) i_{m}\right]$ plus the opportunity cost of the equity invested in the house $\left[(1-\mu)\left(r_{n}+\pi\right)\right]$ plus the local property tax reduced by the value of the corresponding tax deduction $\left[(1-\theta) \tau_{p}\right]$ plus the maintenance $[\mathrm{m}]$ and depreciation $[\delta]$ less the inflationary gain on the property $[\pi]$.

In 1991, the year for which other data on housing used in this section were derived, the rate on conventional mortgages was $i_{m}=0.072$ and the rate of inflation was $\pi=0.01 .{ }^{38}$ The assumption that $d \mathrm{i}_{\mathrm{m}} / \mathrm{d} \pi=1$ implies that $\mathrm{i}_{\mathrm{m}}$ would be 0.082 at an inflation rate of $\pi=0.02 .{ }^{39}$ Section 2 derived a value of $r_{n}=0.0405$ for the real net return on a portfolio of debt and equity securities when $\pi=0.02$. With a typical mortgage-to-value ratio among itemizers of $\mu=0.5,{ }^{40} \mathrm{a}$

${ }^{37}$ Following Poterba (1992) I assume that $\tau_{\mathrm{p}}=0.025$.

${ }^{38}$ The CPI rose by 3.1 percent from December 1990 to December 1991, implying a "true" inflation rate of 1.1 percent. While previous rates were higher, subsequent inflation rates have been lower.

${ }^{39}$ The assumption that $\mathrm{di} / \mathrm{d} \pi=1$ is the same assumption made in section 2 . See footnote 24 above for the reason that I use this approximation.

${ }^{40}$ The relevant $\mu$ ratio is not that on new mortgages or on the overall stock of all mortgages but on the stock of mortgages of itemizing taxpayers. The Balance Sheets for the US Economy indicate that the ratio of home mortgage debt to the value of owner-occupied real estate 
marginal tax rate of $\theta=0.25$, a property tax rate of $\tau_{p}=0.025, \mathrm{~m}=0.02$ and $\delta=0.02$, the rental cost per dollar of housing capital for an itemizer when the inflation rate is two percent is $\mathrm{RI}_{2}=$ 0.0998. Thus the combination of the tax rules and a two percent inflation rate reduces the rental cost from 13.2 cents per dollar of housing capital to 9.98 cents per dollar of housing capital.

Consider now the effect of a decrease in the rate of inflation on this implicit rental cost of owner occupied housing:

$$
\mathrm{dRL} / \mathrm{d} \pi=\mu(1-\theta) \mathrm{di}_{\mathrm{m}} / \mathrm{d} \pi+(1-\mu) \mathrm{d}\left(\mathrm{r}_{\mathrm{n}}+\pi\right) / \mathrm{d} \pi-1 .
$$

Section 2 showed that if each percentage point increase in the rate of inflation raises the rate of interest by one percentage point, the real net rate of return on a portfolio of corporate equity and debt decreases from $r_{n}=0.0454$ at $\pi=0$ to $r_{n}=0.0405$ at $\pi=0.02$, i.e., $d r_{n} / d \pi=-0.245$ and $\mathrm{d}\left(\mathrm{r}_{\mathrm{n}}+\pi\right) / \mathrm{d} \pi=0.755$. Thus with $\theta=0.25, \mathrm{dRI} / \mathrm{d} \pi=0.75 \mu+0.755(1-\mu)-1$. For an itemizing homeowner with a mortgage to value ratio of $\mu=0.5, \mathrm{dRI} / \mathrm{d} \pi=-0.25$. Since $\mathrm{RI}_{2}=$ 0.0998 at two percent inflation, $\mathrm{dRI} / \mathrm{d} \pi=-0.25$ implies that $\mathrm{RI}_{1}=0.1048$ at zero inflation. The lower rate of inflation implies a higher rental cost per unit of housing capital and therefore a smaller distortion.

Before calculating the deadweight loss effects of the reduced inflation, it is necessary to derive the corresponding expressions for homeowners who do not itemize their deductions. For such nonitemizers mortgage interest payments and the property tax payments are no longer tax

has increased to 43 percent in 1994. I use a higher value to reflect the fact that not all homeowners are itemizers and that those who do itemize are likely to have higher mortgage-toague rations. The results of this section are not sensitive to the precise level of this parameter. 
deductible, implying that ${ }^{41}$

$$
\mathrm{RN}=\mu \mathrm{i}_{\mathrm{m}}+(1-\mu)\left(\mathrm{r}_{\mathrm{n}}+\pi\right)+\tau_{\mathrm{p}}+\mathrm{m}+\delta-\pi
$$

The parametric assumptions made for itemizers, modified only by assuming a lower mortgage to value ratio among nonitemizers of $\mu=0.2$, implies $\mathrm{RN}_{2}=0.1098$ and $R N_{1}=0.1137$. Both values are higher than the corresponding values for itemizers but both imply substantial distortions that are reduced when the rate of inflation declines from two percent to zero.

Figure 2 shows the nature of the welfare gain from reducing inflation for taxpayers who itemize. The figure presents the compensated demand curve relating the quantity of housing capital demanded to the rental cost of such housing. With no taxes, $R_{0}=0.132$ and the amount

Figure 2: $\quad$ Homeownership Investments

Rental

Equivalent per $\$$ of House

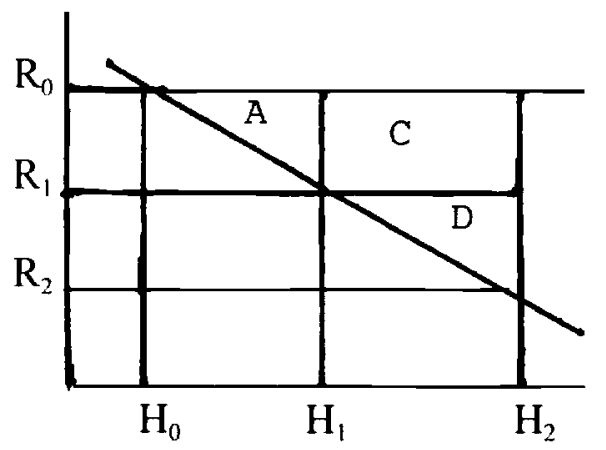

Housing Consumption

${ }^{41}$ This formulation assumes that taxpayers who do not itemize mortgage deductions do not itemize at all and therefore do not deduct property tax payments. Some taxpayers may in fact itemize property tax deductions even though they no longer have a mortgage. 
of housing demanded is $\mathrm{H}_{0}$. The combination of the existing tax rules at zero inflation reduces the rental cost to $R I_{1}=0.1048$ and increases housing demand to $H_{1}$. Since the real pretax cost of providing housing capital is $\mathrm{R}_{0}$, the tax-inflation combination implies a deadweight loss shown by area A, i.e., the area between the cost of providing the additional housing and the demand curve. A rise in inflation to two percent reduces the rental cost of housing further to $\mathrm{RI}_{2}$ $=0.0998$ and increases the demand for housing to $\mathrm{H}_{2}$. The additional deadweight loss is the area $\mathrm{C}+\mathrm{D}$ between the real pretax cost of providing the increased housing and the value to the users as represented by the demand curve.

Thus, the reduction in the deadweight loss that results from reducing the distortion to housing demand when the inflation rate declines from two percent to zero is

$$
G_{3}=\left(R_{0}-R_{1}\right)\left(H_{2}-H_{1}\right)+0.5\left(R_{1}-R_{2}\right)\left(H_{2}-H_{1}\right) .
$$

With a linear approximation,

$$
\begin{aligned}
\mathrm{G}_{3} & =\left(\mathrm{R}_{0}-\mathrm{R}_{1}\right)(\mathrm{dH} / \mathrm{dR})\left(\mathrm{R}_{2}-\mathrm{R}_{1}\right)+0.5\left(\mathrm{R}_{1}-\mathrm{R}_{2}\right)(\mathrm{dH} / \mathrm{dR})\left(\mathrm{R}_{2}-\mathrm{R}_{1}\right) \\
& =-\left(\mathrm{R}_{2} / \mathrm{H}_{2}\right)(\mathrm{dH} / \mathrm{dR})\left\{\left[\left(\mathrm{R}_{0}-\mathrm{R}_{1}\right) / \mathrm{R}_{2}\right]\left[\left(\mathrm{R}_{1}-\mathrm{R}_{2}\right) / \mathrm{R}_{2}\right]+0.5\left(\mathrm{R}_{1}-\mathrm{R}_{2}\right)^{2} \mathrm{R}_{2}^{-2}\right\} \mathrm{R}_{2} \mathrm{H}_{2} .
\end{aligned}
$$

Writing $\varepsilon_{\mathrm{HR}}=-\left(\mathrm{R}_{2} / \mathrm{H}_{2}\right)(\mathrm{dH} / \mathrm{dR})$ for the absolute value of the compensated elasticity of housing demand with respect to the rental price (at the observed values of observed values of $R_{2}$ and $\mathrm{H}_{2}$ ) and substituting the rental values for an itemizing taxpayer yields

$$
\begin{aligned}
\mathrm{GI}_{3} & =\varepsilon_{\mathrm{HR}}\left\{(0.273)(0.050)+0.5(0.050)^{2}\right\} \mathrm{RI}_{2} \mathrm{HI}_{2} \\
& =0.0149 \varepsilon_{\mathrm{HR}} \mathrm{RI}_{2} \mathrm{HI}_{2} .
\end{aligned}
$$


a similar calculation for nonitemizing homeowners yields

$$
\mathrm{GN}_{3}=0.0065 \varepsilon_{\mathrm{HR}} \quad \mathrm{RN}_{2} \mathrm{HN}_{2}
$$

Combining these two on the assumption that the compensated elasticities of demand are the same for itemizers and nonitemizers gives the total welfare gain from the reduced distortion of housing demand that results from reducing equilibrium inflation from two percent to zero:

$$
\mathrm{G}_{3}=\varepsilon_{\mathrm{HR}}\left[0.0149 \mathrm{RI}_{2} \mathrm{HI}_{2}+0.0065 \mathrm{RN}_{2} \mathrm{HN}_{2}\right]
$$

Since the calculations of the rental rates take into account the mortgage to value ratios, the relevant measures of $\mathrm{HI}_{2}$ and $\mathrm{HN}_{2}$ are the total market values of the owner occupied housing of itemizers and nonitemizers. In 1991, there were 60 million owner occupied housing units and 25 million taxpayers who itemized mortgage deductions. ${ }^{42}$ Since the total 1991 value of owner occupied real estate of $\$ 6,440$ billion includes more than just single family homes (e.g., two family homes and farms), I take the value of owner occupied homes (including the owneroccupiers' portion of two-family homes) to be $\$ 6,000$ billion. The Internal Revenue Service reported that the tax revenue reductions in 1991 due to mortgage deductions were $\$ 42$ billion, implying approximately $\$ 160$ billion of mortgage deductions and therefore about $\$ 2,000$ billion of mortgages. The mortgage to value ratio among itemizers of $\mathrm{m} / \mathrm{v}=0.5$ implies that the market value of housing owned by itemizers is $\mathrm{HI}_{2}=\$ 4,000$ billion. This implies that the value of housing owned by nonitemizers is $\mathrm{HN}_{2}=\$ 2,000$ billion.

${ }^{42}$ The difference between these two figures reflects the fact that many homeowners do not itemize mortgage deductions (because they have such small mortgages that they benefit more from using the standard deduction or have no mortgage at all) and that many homeowners own more than one residence. 
Substituting these estimates into equation 22 (with $\mathrm{RI}_{2}=0.0998$ and $\mathrm{RN}_{2}=0.1098$ ) implies that

$$
\mathrm{G}_{3}=\$ 7.4 \varepsilon_{\mathrm{HR}} \text { billion. }
$$

Using Rosen's (1985) estimate of $\varepsilon_{\mathrm{HR}}=0.8$ implies that this gain from reducing the inflation rate is $\$ 5.9$ billion at 1991 levels. Since the 1991 GDP was $\$ 5,723$ billion, this gain is 0.10 percent of GDP.

\subsection{The Revenue Effects of Lower Inflation on the Subsidy to Owner Occupied Housing}

The $G_{3}$ gain is based on the traditional assumption that changes in tax revenue do not affect economic welfare because they can be offset by other lump sum taxes and transfers. The more realistic assumption that increases in tax revenue permit reductions in other distortionary taxes implies that it is important to calculate also the reduced tax subsidy to housing that results from a lower rate of inflation.

The magnitude of the revenue change depends on the extent to which the reduction in inflation shifts capital from owner occupied housing to the business sector. To estimate this I use the compensated elasticity of housing with respect to the rental value, ${ }^{43} \varepsilon_{\mathrm{HR}}=0.8$. The 5 percent increase in the rental price of owner occupied housing for itemizers from $\mathrm{RI}_{2}=0.0998$ at $\pi=$ 0.02 to $\mathrm{RI}_{1}=0.1048$ at zero inflation implies a 4 percent decline in the equilibrium stock of owner-occupied housing, from $\$ 4,000$ billion to $\$ 3,840$ billion (at 1991 levels). Similarly, for nonitemizers, the 3.6 percent increase in the rental price from $\mathrm{RN}_{2}=0.1098$ at $\pi=0.02$ to $\mathrm{RN}_{1}=$

${ }^{43}$ I use the compensated elasticity because other taxes are adjusted to keep total revenue constant. See footnote 33 . 
0.1137 at zero inflation implies a 2.9 percent decline in their equilibrium stock of owneroccupied housing, from $\$ 2,000$ billion to $\$ 1,942$ billion (at 1991 levels).

Consider first the reduced subsidy on the $\$ 3,840$ billion of remaining housing stock owned by itemizing taxpayers. Maintaining the assumption of a mortgage to value ratio of $\mu=$ 0.5 implies total mortgages of $\$ 1,920$ billion on this housing capital. The two percentage point decline in the rate of inflation reduces mortgage interest payments by $\$ 38.4$ billion and, assuming a 25 percent marginal tax rate, increases tax revenue by $\$ 9.6$ billion.

The shift of capital from owner occupied housing to the business sector affects revenue in three ways. First, the itemizers lose the mortgage deduction and property tax deduction on the $\$ 160$ billion of reduced housing capital. The reduced capital corresponds to mortgages of $\$ 80$ billion and, at the initial inflation rate of two percent, of mortgage interest deductions of 8.2 percent of this $\$ 80$ billion or $\$ 6.6$ billion. The reduced stock of owner occupied housing also reduces property tax deductions by 2.5 percent of $\$ 160$ billion of foregone housing, or $\$ 4$ billion. Combining these two reductions in itemized deductions ( $\$ 10.6$ billion) and applying a marginal tax rate of 25 percent implies a revenue gain of $\$ 2.6$ billion.

Second, the increased capital in the business sector $(\$ 160$ billion from itemizers plus $\$ 58$ billion from nonitemizers) earns a pretax return of 9.2 percent but provides a net-of-tax yield to investors of only 4.54 percent when the inflation rate is zero. The difference is the tax collections of 4.66 percent on the additional $\$ 218$ billion of business capital or $\$ 10.2$ billion of additional revenue.

Third, the reduced housing capital causes a loss of property tax revenue equal to 2.5 percent of the $\$ 218$ billion reduction in housing capital or $\$ 5.4$ billion. 
Combining these three effects on revenue implies a net revenue gain of $\$ 16.9$ billion or 0.30 percent of GDP (at 1991 levels).

\subsection{The Welfare Gain from the Housing Sector Effects of Reduced Equilibrium Inflation}

The total welfare gain from the effects of lower equilibrium inflation on the housing sector is the sum of (1) the traditional welfare gain from the reduced distortion to housing consumption, 0.10 percent of GDP; and (2) the welfare consequences of the $\$ 16.9$ billion revenue gain, a revenue gain of 0.30 percent of GDP. If each dollar of revenue raised from other taxes involves a deadweight loss of $\lambda$, this total welfare gain of shifting from four percent inflation to two percent inflation is

$$
\mathrm{G}_{4}=[0.0010+.0030 \lambda] \mathrm{GDP}
$$

The conservative Ballard, Shoven and Whalley (1985) estimate of $\lambda=0.4$ implies that the total welfare gain of reducing inflation from two percent to zero is 0.22 percent of GDP. With the value of $\lambda=1.5$ implied by the behavioral estimates for the effect of an across the board increase in all personal income tax rates, the total welfare gain of reducing inflation from two percent to zero is 0.55 percent of GDP. These are shown in row 4 of Table 1 .

Before combing this with the gain from the change in the taxation of savings and comparing the sum to the cost of reducing inflation, I turn to two other ways in which a lower equilibrium rate of inflation affects economic welfare through the government's budget constraint.

\section{Seigniorage and the Distortion of Money Demand}

An increase in inflation raises the cost of holding non-interest-bearing money balances and therefore reduces the demand for such balances below the optimal level. Although the 
resulting deadweight loss of inflation has been the primary focus of the literature on the welfare effects of inflation since Bailey's (1956) pioneering paper, the effect on money demand of reducing the inflation rate from two percent to zero is small relative to the other effects that have been discussed in this paper. ${ }^{44}$

This section follows the framework of sections 2 and 3 by looking first at the distortion of demand for money and then at the revenue consequences of the inflation "tax" on the holding of money balances.

\subsection{The Welfare Effects of Distorting the Demand for Money}

As Milton Friedman (1969) has noted, since there is no real cost to increasing the quantity of money, the optimal inflation rate is such that it completely eliminates the cost to the individual of holding money balances, i.e., the inflation rate should be such that the nominal interest rate is zero. In an economy with no taxes on capital income, the optimal inflation rate would therefore be the negative of the real rate of return on capital: $\pi *=-\rho$. More generally, if we recognize the existence of taxes, the optimal inflation rate is such that the nominal after-tax return on alternative financial assets is zero.

Recall that at $\pi=0.02$ the real net return on the debt-equity portfolio is $r_{n}=0.0405$ and

${ }^{44}$ Although the annual effect is extremely small, it is a perpetual effect. As I argued in Feldstein (1979), in a growing economy a perpetual gain of even a very small fraction of GDP may outweigh the cost of reducing inflation if the appropriate discount rate is low enough relative to the rate of aggregate economic growth. In the context of the current paper, however, the welfare effect of the reduction in money demand is very small relative to the welfare effects that occur because of the interaction of inflation and the tax laws. 
that $d r_{n} / d \pi=-0.245$. The optimal inflation rate in this context is such that $r_{n}+\pi=0.45$

Figure 3 illustrates the reduction in the deadweight loss that results if the inflation rate is reduced from $\pi=0.02$ to zero, thereby reducing the opportunity costs of holding money balances from $r_{n}+\pi=0.0605$ to the value of $r_{n}$ at $\pi=0$, i.e., $r_{n}=0.0454$. Since the opportunity cost of supplying money is zero, the welfare gain from reducing inflation is the area $\mathrm{C}+\mathrm{D}$ between the money demand curve and the zero opportunity cost line:

\section{Figure 3: $\quad$ Money Demand and Seignoriage}

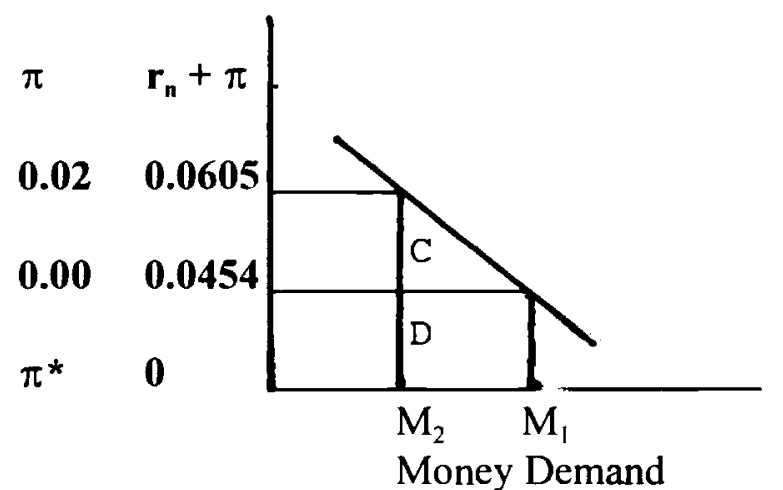

$$
\begin{aligned}
\mathrm{G}_{5} & =0.0454\left(\mathrm{M}_{1}-\mathrm{M}_{2}\right)+0.5(0.0605-0.0454)\left(\mathrm{M}_{1}-\mathrm{M}_{2}\right) \\
& =0.0530\left(\mathrm{M}_{1}-\mathrm{M}_{2}\right) \\
& =-0.0530\left[\mathrm{~d} \mathrm{M} / \mathrm{d}\left(\mathrm{r}_{\mathrm{n}}+\pi\right)\right](0.0151) \\
& =0.00080 \varepsilon_{\mathrm{M}} \mathrm{M}\left(\mathrm{r}_{\mathrm{n}}+\pi\right)^{-1}
\end{aligned}
$$

where $\varepsilon_{\mathrm{M}}$ is the elasticity of money demand with respect to the nominal opportunity cost of holding money balances and $r_{n}+\pi=0.0605$.

${ }^{45}$ If $\mathrm{dr}_{\mathrm{n}} / \mathrm{d} \pi$ remains constant, the optimal rate of inflation is $\pi *=-0.060$. Although this assumption of linearity may not be appropriate over the entire range, the basic property that $r_{n}>\pi^{*}>-\rho$ is likely to remain valid in a more exact calculation, reflecting the interaction between taxes and inflation. 
Since the demand deposit component of M1 is now generally interest bearing, noninterest-bearing money is now essentially currency plus bank reserves. In 1994, currency plus reserves were 6.1 percent of GDP. Thus, $M=0.061$ GDP. There is a wide range of estimates of the elasticity of money demand, corresponding to different definitions of money and different economic conditions. An estimate of $\varepsilon_{\mathrm{M}}=0.2$ may be appropriate in the current context with money defined as currency plus bank reserves. ${ }^{46}$ With these assumptions, $\mathrm{G}_{5}=0.00016$ GDP. Thus even when Friedman's standard for the optimal money supply is used, the deadweight loss due to the distorted demand for money balances is only 0.0002 GDP.

\subsection{The Revenue Effects of Reduced Money Demand}

The decline in inflation affects government revenue in three ways. First, the reduction in the inflation "tax" on money balances results in a loss of seigniorage and therefore an associated welfare loss of raising revenue by other distortionary taxes (Phelps, 1973). In equilibrium, inflation at rate $\pi$ implies revenue equal to $\pi \mathrm{M}$. Increasing the inflation rate raises the seigniorage revenue by

$$
\text { d Seignorage } / \mathrm{d} \pi=\mathrm{M}+\pi(\mathrm{dM} / \mathrm{d} \pi)
$$

${ }^{46}$ In Feldstein (1979) I assumed an elasticity of one-third for non-interest-bearing M1 deposits. I use the lower value now to reflect the fact that the non-interest-bearing money is now just currency plus bank reserves. These are likely to be less interest sensitive than the demand deposit component of $\mathrm{Ml}$. The assumption that $\varepsilon_{\mathrm{M}}=0.2$ when the opportunity cost of holding money balances is approximately 0.06 implies that a one percentage point increase in $r_{n}+\pi$ reduces $\mathrm{M}$ by approximately $.2(0.01) / 0.06=0.033$, a semi-elasticity of 3.3 . Since the Cagan (1956) estimates of this semi-elasticity ranged from $F=3$ to $F=10$, the selection of $\varepsilon_{M}=0.2$ In the current context may be quite conservative. 


$$
\begin{aligned}
& =M+\pi\left[d M / d\left(r_{n}+\pi\right)\right]\left[d\left(r_{n}+\pi\right) / d \pi\right] \\
& =M\left\{1-\varepsilon_{M}\left[d\left(r_{n}+\pi\right) / d \pi\right] \pi\left(r_{n}+\pi\right)^{-1}\right\}
\end{aligned}
$$

With $\mathrm{M}=0.061 \mathrm{GDP}, \varepsilon_{\mathrm{M}}=0.2, \mathrm{~d}\left(\mathrm{r}_{\mathrm{n}}+\pi\right) / \mathrm{d} \pi=0.755, \pi=0.02$ and $\mathrm{r}_{\mathrm{n}}+\pi=0.0605$, equation 26 implies that $\mathrm{d}$ ( Seignorage) $/ \mathrm{d} \pi=0.058$ GDP. A decrease of inflation from $\pi=0.02$ to $\pi=0$ causes a loss of seignorage of 0.116 percent of GDP.

The corresponding welfare loss is $0.116 \lambda$ percent of GDP. With $\lambda=0.4$, the welfare cost of the lost seignorage is 0.046 percent of GDP. With $\lambda=1.5$, the welfare cost of the lost seignorage is 0.174 percent of GDP.

The second revenue effect is the revenue loss that results from shifting capital to money balances from other productive assets. ${ }^{47}$ The decrease in business capital is equal to the increase in the money stock, $M_{1}-M_{2}=\left[d M / d\left(r_{n}+\pi\right)\right](0.0151)=0.0151 \varepsilon_{M} M\left(r_{n}+\pi\right)^{-1}=0.30$ percent of GDP. When these assets are invested in business capital, they earn a real pretax return of 9.2 percent but a net of tax return of only 4.54 percent. The difference is the corporate and personal tax payments of 4.66 percent. Applying this to the incremental capital of 0.30 percent of GDP implies a revenue loss of $0.0466(0.30)=0.014$ percent of GDP. The welfare gain from this extra revenue is $0.014 \lambda$ percent of GDP. With $\lambda=0.4$, the welfare loss from this source is 0.006 percent of GDP while, with $\lambda=1.5$, the loss is 0.021 percent of GDP.

The final revenue effect of the change in the demand for money is the result of the government's ability to substitute the increased money balance of $M_{1}-M_{2}$ for interest bearing

\footnotetext{
${ }^{47}$ This is analogous to the revenue gain associated with the shift of assets from housing into business capital discussed in section 3 .
} 
government debt. Although this is a one time substitution, it reduces government debt service permanently by $r_{n g}\left(M_{1}-M_{2}\right)$ where $r_{n g}$ is the real interest rate paid by the government on its outstanding debt net of the tax that it collects on those interest payments. A conservative estimate of $r_{n g}$, based on the observed 1994 ratio of interest payments to national debt of 0.061 , an assumed tax rate of 0.25 and a 1994 inflation rate of 2.7 percent is $r_{n g}=0.75(0.061)-0.027=$ 0.018 . The reduced debt service cost in perpetuity is thus $0.018\left(\mathrm{M}_{1}-\mathrm{M}_{2}\right)=0.000054 \mathrm{GDP}$. The corresponding welfare gains are 0.002 percent of GDP at $\lambda=0.4$ and 0.008 percent of GDP at $\lambda=1.5$.

Combining these three effects yields a net welfare loss due to decreased revenue of 0.05 percent of GDP if $\lambda=0.4$ and of 0.19 percent of GDP if $\lambda=1.5$.

Although all of the effects that depend on the demand for money are small, the welfare loss from reduced seignorage revenue is much larger than the welfare gain from the reduced distortion of money demand and the shift of assets to taxpaying business investments. When considering this small reduction in inflation, the Phelps revenue effect dominates the Bailey money demand effect.

\section{Debt Service and the Government Budget Constraint}

The final effect of reduced inflation that I will consider is the higher real cost of servicing the national debt that results from a reduction in the rate of inflation. This higher debt service cost occurs because inflation leaves the real pretax interest rate on government debt unchanged while the inflation premium is subject to tax at the personal level. A lower inflation rate therefore does not change the pretax cost of debt service but reduces the tax revenue on the 
government debt payments. This in turn requires a higher level of other distortionary taxes. ${ }^{48}$

To assess the effect of inflation on the net cost of debt service, note that the increase in the outstanding stock of government debt (B) can be written as

$$
\Delta B=\left(r_{g}+\pi\right) B+G-T-\theta_{i}\left(r_{g}+\pi\right) B,
$$

where $\left(r_{g}+\pi\right)$ is the nominal pretax interest rate of government debt and $\theta_{i}$ is the effective rate of tax on such interest payments. Thus $\left(r_{g}+\pi\right) B$ is the gross interest payment on the government debt and $\left(1-\theta_{i}\right)\left(r_{\mathrm{g}}+\pi\right) B$ is the net interest on that debt. $G$ is all other government spending and $\mathrm{T}$ is all tax revenue other than the revenue collected from taxing the interest on government debt.

In equilibrium, the stock of government debt must grow at the same rate as nominal GDP, i.e., $\Delta B=B(n+g+\pi)$ where $n$ is the rate of growth of population and $g$ is the rate of growth per capita output. Combining this equilibrium condition with equation 27 implies

$$
\mathrm{T} / \mathrm{GDP}=\mathrm{G} / \mathrm{GDP}+\left[\left(1-\theta_{\mathrm{i}}\right) \mathrm{r}_{\mathrm{g}}-\mathrm{n}-\mathrm{g}-\theta_{\mathrm{i}} \pi\right] \mathrm{B} / \mathrm{GDP}
$$

Thus, $\mathrm{d}(\mathrm{T} / \mathrm{GDP}) / \mathrm{d} \pi=-\theta_{\mathrm{i}}(\mathrm{B} / \mathrm{GDP})$.

Reducing the inflation rate from two percent to zero increases the real cost of debt service (i.e., increases the level of taxes required to maintain the existing debt/GDP ratio) by $0.02 \theta_{i} \mathrm{~B}$. With $\theta_{i}=0.25$ and the current debt to GDP ratio of $\mathrm{B} / \mathrm{GDP}=0.5$, the two percentage point reduction would reduce tax revenue by 0.25 percent of GDP and would therefore reduce welfare by $0.25 \lambda$ percent of GDP. The welfare cost of increased net debt service is therefore between

${ }^{48}$ Note that the effect of inflation on business tax revenue (through the tax-inflation interaction on depreciation and corporate debt) has been counted in the above discussion of taxes and saving. This ignores the role of retained earnings and the effect of changes in the mixture of corporate investment on the overall tax revenue. 
0.10 percent of GDP and 0.38 percent of GDP, depending on the value of $\lambda$. These figures are shown in row 6 of Table 1.

\section{The Net Effect of Lower Inflation on Economic Welfare}

We can now bring together the several effects of reduced inflation that have been identified and evaluated in sections 2 through 5 and compare them with the one-time output losses required to achieve that inflation reduction that were discussed in section 1 .

Table 1 summarizes the four effects, distinguishing the direct effects of reduced distortion and the indirect effects that occur through the change in revenue. Separate values are given for the alternative savings demand elasticities $\left(\eta_{\mathrm{Sr}}=0.4, \eta_{\mathrm{Sr}}=0\right.$ and $\left.\eta_{\mathrm{Sr}}=1.0\right)$ and for the alternative estimates of the deadweight loss per dollar of revenue raised through alternative distorting taxes $(\lambda=0.4$ and $\lambda=1.5)$.

These relatively large gains from reduced inflation reflect primarily the fact that the existing system of capital taxation imposes large deadweight losses even in the absence of inflation and that these deadweight losses are exacerbated by inflation.

Reducing these distortions by lowering the rate of inflation produces annual welfare gains of 1.14 percent of GDP in the benchmark saving case where there is a very small positive relation between saving and the real net rate of interest $\left(\eta_{\mathrm{Sr}}=0.4\right)$. The deadweight loss distortions in the other two cases, also shown at the bottom of column 1 , are 0.85 percent of GDP and 1.56 percent of GDP.

The additional welfare effects of changes in revenue, summarized at the bottom of columns 3 and 4) can be either negative or positive but on balance are smaller than the direct 
effects of reduced distortion. In the benchmark case of $\eta_{\mathrm{Sr}}=0.4$, the total revenue effects reduce welfare but the reductions are relatively small (between -0.13 at $\lambda=0.4$ and -0.51 at $\lambda=1.5$ ).

The total welfare effect of reducing inflation from two percent to zero is therefore a gain in the benchmark saving case of between 0.63 percent of GDP a year and 1.01 percent of GDP a year. A higher saving response increases the net gain while a lower saving response reduces it.

If the cost of reducing the inflation rate from two percent to zero is a one-time cumulative loss of six percent of GDP, as Ball's (1995) analysis discussed in section 1 implies, the estimated gains in the benchmark case would offset this cost within six to eight years. If savings are more responsive, the gain from price stability would offset the cost even more quickly. Only if saving is completely interest inelastic and revenue raising has a high deadweight loss does the estimated total effect imply that the welfare gains would take more than a decade to exceed the lost GDP that is required to achieve price stability. Even in this case, the present value of the annual benefits of eliminating inflation exceeds 10 percent of the initial GDP if the growing benefit stream is discounted by the historic real return on the Standard and Poors portfolio.

\section{The Limits of Indexing}

Since the gains from reduced inflation that are evaluated in this paper reflect the interaction of taxes and inflation, it is natural to ask whether the same gains might not be achieved without a loss of output by indexing the tax system. While this would in theory be possible, this section will explain some of the reasons why that is not a practical alternative to reducing inflation. 
It should be noted from the outset that there is a long history of proposal to index the tax system motivated not only by the desire to reduce the deadweight losses of the type discussed in this paper but also because a tax system that bases taxes on nominal capital income and expenses is regarded as inherently unfair. Individuals pay capital gains taxes even if they have real losses. The effective tax rate on interest income may exceed 100 percent even if the statutory rate is only 25 percent. Allowing only nominal depreciation on plant and equipment can substantially reduce the return on business investment during times of relatively high inflation. All of these issues received heightened public and professional attention in the late 1970s and early 1980s when U.S. inflation rates exceeded 10 percent.

Despite public and professional support for indexing and proposals by the Reagan administration to introduce such indexing, the taxation of capital income remains unindexed. ${ }^{49}$ The United States is not alone in not indexing the taxation of capital income. In no major industrial country are taxes levied only on real income and deductions allowed only for real expenses. ${ }^{50}$ The reasons are partly technical, partly administrative and partly, as in Germany, a matter of political conviction. This section will comment on each type of reason.

Consider first the technical "legal" problems of designing rules about what should be indexed and what should not. In principle the problem is easy. Interest income should be taxed

${ }^{49}$ Although tax brackets are adjusted for the rise in the price level, this does nothing to remedy the mismeasurement of capital income and expenses.

${ }^{50}$ Some countries have indexed some part of their tax laws. In the UK capital gains are taxed on an inflation adjusted basis and only above a substantial annual exclusion. Mexico has probably gone further than any other OECD country in adopting the indexation principles first outlined by the Carter Commission in Canada in the 1960s but even Mexico has not provided full indexation. The Canadians never adopted the indexation proposals of the Carter Commission. 
only after subtracting the product of the inflation rate and the principle of the fixed income asset. Thus a bond with a market price of $\$ 100$ that pays interest of $\$ 7$ in a year in which the price level rose by four percent would create taxable income of only $\$ 3 .{ }^{51}$ In contrast, the dividend income on a stock should be taxed in full because the value of the underlying equity is not fixed in nominal terms and should in principle rise with the general price level. When the stock is sold, a capital gain would be taxed only to the extent that the nominal value of the asset rises by more than the increase in the price level.

But the world consists of more than such "plain vanilla" bonds and stocks. Consider a convertible bond. If the price of the stock is high enough relative to the conversion price and the bond can currently be converted, the bond has all of the "inflation protection" attributes of the stock (as well as the extra protection of a fixed interest obligation). How should such a convertible bond be taxed? If the "bond" is trading in the market like a stock, it might seem reasonable to tax it like a stock and not allow any inflation adjustment even though the annual payments are called "interest" payments. Failure to do so might encourage companies to issue short term convertible bonds below the conversion price. But a general rule that convertible bonds should be taxed like equity would not be appropriate for a bond that has a conversion price far above the actual price of the stock and is therefore trading like a bond.

To take another simple but realistic example, consider commercial mortgages in which

${ }^{51}$ Even in this simple case there is a problem if the nominal price of the bond fluctuates during the year. Does one use the beginning or the end or the average value? If some "reasonable" but arbitrary compromise like using the beginning of year value is used, will sophisticated investors trade such bonds to get unfair (and distorting) real net of tax interest rates? 
the interest and principle are linked to the rents in the building or, in the case of stores, to the gross nominal receipts of the store. What if the mortgage pays the higher of some fixed nominal amounts and the rent linked amount? Should these mortgage payments be treated like debt or equity? How should they be treated to the borrower?

Any rule that tries to draw a line between debt and equity for the purpose of inflation adjustment will create powerful incentives to create tax-advantaged securities. The ability to create derivative securities tailored to the tax law makes this problem even worse because it would allow investors to have and to trade the tax-advantaged features of securities without having other attributes that they do not want. In the case of the index linked mortgage, it would be possible to strip out the excess, if any, of the index linked portion over the fixed income portion. How should that derivative security be taxed?

In addition to the technical legal problems there are purely administrative problems. Consider for example the problem of inflation adjusting interest receipts on securities held for only part of a year. In principle the solution is easy. But consider the administrative problem for an individual who transfers money frequently into and out of a saving account or checking account.

Again, any simplification or rough approximation would provide an incentive for sophisticated investors to move large sums of money to take advantage of the opportunity to borrow and lend under different tax rules. These problems of micro-timing may not matter much when the inflation rate is low, but any tax rule should be applicable in higher inflation rate environments.

Consider next the special problem of indexing capital gains. This has been a frequent 
proposal in the Congress over the past two decades and has received bipartisan support because of the widely perceived unfairness of taxing nominal "profits" when the real gains on those transactions are negative. The basic idea would be to increase the "cost" for the purpose of calculating taxable gain by the ratio of the price level at the time of sale to the price level at the time that the asset was purchased. If this adjustment is permitted to create taxable losses when the rise in the nominal value of the security is less than the rise in the price level, it is likely that the capital gains tax would cease to collect any revenue at all. Since individuals can decide when to realize gains and losses, it is very likely that individuals holding a widely diversified portfolio could always find enough stocks with real losses to offset the real taxable gains on those stocks that they choose to sell. ${ }^{52}$ To avoid this result, indexation proposals in the Congress would not allow individuals to take a loss when the nominal value of the asset has not fallen. If such legislation were to pass, it would create the incentive to produce new conglomerate securities that preserved as much as possible of this tax advantage. The indexing rule would substitute one distortion for another. ${ }^{53}$

${ }^{52}$ Recall that under current law assets held until death are not subject to a capital gains tax in the hands of either the decedent or the heir; the "cost" of the asset is "stepped up" to the market value at the time of the owner's death and subsequent gains are calculated only relative the value at that time.

${ }^{53}$ It is of course easy to suggest that these problems could be remedied by more fundamental reforms of the taxation of capital gains. It would take this paper too far afield to discuss some of the reasons why proposals like accrual taxation of gains are not practical solutions. 
Consider finally the tax treatment of owner-occupied housing. It would in principle be possible to limit the mortgage deduction only to the real component of the mortgage payment. ${ }^{54}$ That would of course create incentives for individuals who can do so to borrow in other more tax-favored ways. But even apart from that, it is clear from the analysis of section 3 that limiting the mortgage deduction alone does very little to reduce the distortion and the revenue loss associated with the current tax treatment of owner occupied housing. As the analysis there showed, reducing the inflation rate from two percent to zero would produce a substantial welfare gain even for those who do not currently itemize their mortgage deductions at all.

In addition to these technical and administrative problems, there is a more fundamental concern that an indexed tax system might lead to less public support for anti-inflationary policies. If the tax indexing serves only to reduce but not to eliminate the adverse effects of inflation but leads to policies that produce a higher rate of inflation, the net effect of indexing on economic welfare may be negative..$^{5 s}$

\section{Conclusion}

The calculations in this paper imply that the interaction of existing tax rules and inflation cause a significant welfare loss even at a low rate of inflation. More specifically, the analysis implies that shifting the equilibrium rate of inflation from two percent to zero would cause a

${ }^{54}$ I should emphasize "in principle" because any attempt to limit mortgage deductions meets with overwhelming political objections. In a nation of 60 million homeowners, even those who do not currently have mortgages worry rightly that limiting the mortgage deduction would reduce the value of their largest asset.

${ }^{55}$ This is the argument developed in Fischer and Summers (1989). It is the logic that underlies the German constitutional prohibition against any kind of indexing. 
perpetual welfare gain equal to about one percent of GDP a year. The deadweight loss of two per cent inflation is so large because inflation exacerbates the distortions that would be caused by existing capital income taxes even with price stability.

To assess the desirability of achieving price stability, the gain from eliminating this loss has to be compared to the one-time cost of disinflation. Shifting from two percent inflation to price stability is estimated to have a cost equal to about five percent of GDP. Since the one percent of GDP annual welfare gain from price stability continues forever and grows at the same rate as GDP (i.e., at about 2.5 percent a year), the present value of the welfare gain is very large. Discounting the annual gains at the rate that investors require for risky equity investments (i.e., at the 5.1 percent real net-of-tax rate of return on Standard and Poors portfolio from 1969 to 1994) implies a present value gain equal to more than 35 percent of the initial level of GDP. The benefit of achieving price stability therefore substantially exceeds its cost.

This welfare gain could in principle also be achieved by eliminating all capital income taxes or by indexing capital income taxes so that taxes are based only on real income and real expenses. The paper has discussed the technical and administrative difficulties that are likely to keep such indexing from being adopted. Although some of the current tax reform proposals would eliminate capital income taxation, their prospects are very uncertain. The magnitude of the annual gain from reducing inflation is so large that the expected present value of the gain from disinflating from two percent inflation to price stability would be positive even if there were a 50 percent chance that capital income taxes would be completely eliminated after ten years.

The analysis of this paper does not discuss the distributional consequences of the disinflation or of the reduced inflation. Some readers may believe that the output loss caused by $\operatorname{lnf} .4 / 020496$ 
the disinflation should be weighted more heavily than the gain from low inflation because the output loss falls disproportionately on lower income individuals and does so in the form of the large individual losses associated with unemployment. It would however take very large weights to overcome the difference between the five percent of GDP output loss of disinflation and the 35-plus percent of GDP present value gain from lower inflation.

The analysis of this paper could be extended in several ways. The paper presents estimates of the annual steady state gain from lower inflation. To get a more accurate calculation of the present value, it would be desirable to study the time path of those gains. A more complete measure of the effects of inflation on saving and on the timing of consumption would extend the analysis to precautionary saving and to institutional saving in pensions and insurance. It would also be desirable to look at the deadweight losses and revenue effects of the impact of inflation on business investment.

Although the current research has shown that shifting from low inflation to price stability is likely to raise economic welfare, the paper has not derived the optimal rate of inflation. The large literature on that subject, starting with the contributions of Friedman (1969) and Phelps (1973), has focused on the distortion to money demand and the resulting seigniorage gain. As the present paper shows, those effects are much smaller than the effects caused by the interaction of inflation and capital taxation. A future paper will report the implications of the current analysis for the optimal rate of inflation.

Cambridge, MA

February 1996 


\section{References}

Auerbach, Alan. (1978) "Appendix: The Effect of Inflation on the Tax Value of Depreciation," in Martin Feldstein, Jerry Green and Eytan Sheshinki, "Inflation and Taxes in a Growing Economy with Debt and Equity Finance," Journal of Political Economy, Part 2, pp S68S69, April 1978.

Bailey, Martin. (1956) "The Welfare Cost of Inflationary Finance, Journal of Political Economy, 64, pp. 93-110.

Ball, Laurence. (1994) "What Determines the Sacrifice Ratio?", in Monetary Policy, N.G. Mankiw (ed.). Chicago: The University of Chicago Press, 1994.

Ballard, Charles and John Shoven and John Whalley. "General Equilibrium Computations of the Marginal Welfare Cost of Taxes in the United States," American Economic Review, 75 (March 1985), pp 128-38.

Barro, Robert. (1995) "Inflation and Economic Growth," NBER Working Paper No. 5326, October 1995.

Benabou, Roland. (1992) "Inflation and Efficiency in Search Markets," Review of Economic Studies, 59(2), pp 299-329.

Blinder, Alan. (1975) “Distribution Effects and the Aggregate Consumption Function," Journal of Political Economy, Vol. 83, No. 3, pp 447-75, June 1975.

Boskin, Michael. (1978) "Taxation, Saving and the Rate of Interest, Journal of Political Economy, Part 2, pp S3-27, April 1978.

Cagan, Phillip. (1953) "The Monetary Dynamics of Hyperinflation", in Studies in the Quantity Theory of Money in M. Friedman (ed.) Chicago: University of Chicago Press, 1953.

Evans, O. (1983) "Tax Policy, the Interest Elasticity of Saving, and Capital Accumulation, American Economic Review, pp 398-410, June 1983.

Feldstein, Martin. (1979) "The Welfare Cost of Permanent Inflation and Optimal Short-Run Economic Policy," Journal of Political Economy, Vol. 87, No. 4, pp 749-768.

Feldstein, Martin. (1978) “The Welfare Cost of Capital Income Taxation,” Journal of Political Economy, Vol. 86, No. 2, Part 2, pp S29-51. 
Feldstein, Martin. (1983) Inflation. Tax Rules and Capital Formation, Chicago: University of Chicago Press.

Feldstein, Martin. (1995a) "Tax Policy and International Capital Flows," The 1994 Bernhard Harms Prize Lecture, Welwirtshaftsliches Archiv, 1994:4, pp. 675-697 and NBER Working Paper No. 4851, June 1994.

Feldstein, Martin. (1995b) "Tax Avoidance and the Deadweight Loss of the Income Tax," NBER Working Paper No. 5055.

Feldstein, Martin. (1995c) "The Effect of Marginal Tax Rates on Taxable Income: A Panel Study of the 1986 Tax Reform Act," Journal of Political Economy, June 1995, (103:3), pp. 551-572.

Feldstein, Martin. (1995b) "Fiscal Policies, Capital Formation and Capitalism," The 1994 Joseph Schumpeter Lecture to the European Economic Association, European Economic Review, 39 (1995), pp 399-420.

Feldstein, Martin, Jerry Green and Eytan Sheshinski. (1978) "Inflation and Taxes in a Growing Economy with Debt and Equity Finance," Journal of Political Economy, Part 2, pp S5370, April 1978.

Feldstein, Martin, James Poterba and Louis Dicks-Mireaux. (1983) "The Effective Tax Rate and the Pretax Rate of Return," Journal of Public Economics, Vol. 21, No. 2, pp. 129-158.

Feldstein, Martin and Daniel Feenberg. (1996) "The Effect of Increased Tax Rates on Taxable Income and Economic Efficiency: A Preliminary Analysis of the 1993 Tax Rate Increases", NBER Working Paper No. 5370. Forthcoming in Tax Policy and the Economy, J. Poterba (ed.).

Fischer, Stanley. (1981) "Towards an Understanding of the Costs of Inflation, II" in The Costs and Consequences of Inflation, K. Brunner and A. Meltzer (eds.), CarnegieRochester Conference Series on Public Policy, Vol. 15, Amsterdam: North Holland.

Fischer, Stanley. (1994) "Modern Central Banking," in The Future of Central Banking, F. Capie, G. Goodhart, S. Fischer, and N. Schnadt, Cambridge: Cambridge University Press.

Fischer, Stanley and Franco Modigliani. (1978) "Toward an Understanding of the Real Effects and Costs of Inflation", Weltertschatftlisches Archiv, No. 114: pp 810-833. 
Fischer, Stanley and Lawrence Summers. (1989) "Should Governments Learn to Live with Inflation", American Economic Review, Vol. 83, No. 1, pp 312-313, March 1983.

Friedman, Milton. (1969) "The Optimum Quantity of Money," in The Optimum Quantity of Money and Other Essays, Chicago: Aldine.

Hall, Robert. (1987) “Real Interest and Consumption," Journal of Political Economy,

Hartman, David. (1979) "Taxation and the Effects of Inflation on the Real Capital Stock in an Open Economy,” International Economic Review (20:2) June 1979 pp 417 - 425.

Makin, John. (1987) "Saving, Pension Contributions and Real Interest Rates, American Enterprise Institute.

Mankiw, N. G. (1978) "Consumer Spending and the After-Tax Real Interest Rate," in M. Feldstein (ed.), The Effects of Taxation on Capital Accumulation, Chicago: University of Chicago Press.

Mishkin, Frederic. (1992). "Is the Fischer Effect for Real?" Journal of Monetary Economics, No. 30, pp 195-215.

Phelps, Edmund. (1973) "Inflation in the Theory of Public Finance," Swedish Journal of Economics, 75, pp. 67-82.

Poterba, James. (1984) "Tax Subsidies to Owner Occupied Housing: An Asset Market Approach," Quarterly Journal of Economics, 99 (1984) pp 729-45.

Poterba, James. (1992) "Taxation and Housing: Old Questions, New Answers," American Economic Review, Vol. 82, No. 2, May 1992, pp 237-242.

Rippe, Richard. (1995) "Further Gains in Corporate Profitability," Economic Outlook Monthly, (published monthly by Prudential Securities, Inc.), August.

Rosen, Harvey. (1985) "Housing Subsidies: Effects on Housing Decisions, Efficiency and Equity," in M. Feldstein and A. Auerbach, (eds.) Handbook of Public Economics, Volume 1, Amsterdam: North Holland Publishing Co., 1985.

Wright, C. (1969) "Saving and the Rate of Interest, in M.J. Bailey (ed.), The Taxation of Income from Capital, Brookings Institution, Washington, DC. 